\title{
Synthesis, Characterization and Biological Activities of Binuclear Metal Complexes of 2-Benzoylpyridine and Phenyl(Pyridin-2-yl) Methanediol Derived from 1-Phenyl-1-(Pyridin-2-yl)-N-(Pyrimidin-2-yl) Methanimine Dihydrate Schiff Base
}

\author{
Francis A. Ngounoue Kamga1, Evans Ngandung Mainsah², Maurice Kuate ${ }^{1}$, Peter T. Ndifon ${ }^{1 *}$ \\ ${ }^{1}$ Department of Inorganic Chemistry, Faculty of Science, University of Yaounde I, Yaoundé, Cameroon \\ ${ }^{2}$ Department of Chemistry, Faculty of Science, University of Buea, Buea, Cameroon \\ Email: *pndifon@yahoo.com
}

How to cite this paper: Kamga, F.A.N., Mainsah, E.N., Kuate, M. and Ndifon, P.T. (2021) Synthesis, Characterization and Biological Activities of Binuclear Metal Complexes of 2-Benzoylpyridine and Phenyl (Pyridin-2-yl)Methanediol Derived from 1Phenyl-1-(Pyridin-2-yl)-N-(Pyrimidin-2-yl ) Methanimine Dihydrate Schiff Base. Open Journal of Inorganic Chemistry, 11, 20-42.

https://doi.org/10.4236/ojic.2021.111002

Received: December 7, 2020

Accepted: January 26, 2021

Published: January 29, 2021

Copyright (๑) 2021 by author(s) and Scientific Research Publishing Inc. This work is licensed under the Creative Commons Attribution International License (CC BY 4.0).

http://creativecommons.org/licenses/by/4.0/ (c) (i) Open Access

\begin{abstract}
The Schiff base, 1-phenyl-1-(pyridin-2-yl)-N-(pyrimidin-2-yl)methanimine dihydrate $\left(\mathrm{L}_{1}\right)$ has been synthesized by the condensation reaction between 2 -aminopyrimidine and 2-benzoylpyridine and characterized using ${ }^{13} \mathrm{C}-\mathrm{NMR}$, ${ }^{1} \mathrm{H}-\mathrm{NMR}$, microanalysis, FT-IR, DEPT-135, HSQC, HMBC, COZY, NOESY. The reaction of 1-phenyl-1-(pyridin-2-yl)-N-(pyrimidin-2-yl)methanimine dihydrate $\left(\mathrm{L}_{1}\right)$ with salts of $\mathrm{V}(\mathrm{IV}), \mathrm{Co}(\mathrm{II})$ and $\mathrm{Cu}(\mathrm{II})$, however, resulted in the hydrolysis of $\mathrm{L}_{1}$ to give binuclear metal complexes of 2-benzoylpyridine $\left(\mathrm{L}_{2}\right)$ and phenyl(pyridin-2-yl)methanediol $\left(\mathrm{L}_{3}\right)$ which were characterized using UV-visible spectroscopy, and TGA. The single crystal x-ray structure determined for the Copper(II) complex revealed that we obtained a compound previously obtained using a different method of synthesis. The Schiff base ligand $\left(\mathrm{L}_{1}\right)$ is soluble in methanol, ethanol, DMSO, acetone and DMF. Microanalysis and Spectroscopic studies indicated that binuclear metal complexes were obtained by the coordination of metal ion to 2-benzoylpyridine $\left(L_{2}\right)$ and phenyl(pyridin-2-yl)methanediol $\left(\mathrm{L}_{3}\right)$ from the hydrolysis of $\mathrm{L}_{1}$. Spectroscopic and elemental analysis reveal the formation of square pyramidal complexes of $\mathrm{Co}(\mathrm{II})$ and $\mathrm{Cu}(\mathrm{II})$ and a square planar complex of $\mathrm{V}(\mathrm{IV})$. In vitro antibacterial and antifungal activity against three bacterial strains (Escherichia coli, Klebsiella pneumoniae and Staphylococcus aureus) and three fungal stains (Candida albicans, Candida glabrata and Candida parapsilosis) showed moderate biological activity. Antioxidant studies reveal that only the binuclear
\end{abstract}


$\mathrm{Co}$ (II) and oxovanadium(II) complexes are potent to eliminate free radicals.

\section{Keywords}

Binuclear Complexes, Schiff Base, 2-Benzoylpyridine, Crystal Structure, Antimicrobial Activity, Antioxidant Activity

\section{Introduction}

Heterocyclic Schiff base ligands containing O- or N-donors and their metal complexes have been shown to exhibit interesting properties [1] [2] [3] and those containing pyrimidine and pyridine rings represent a promising class of compounds due to their inherent biological and pharmaceutical properties [2] [3] [4] [5]. Pyrimidine and pyridine based compounds exhibit a broad spectrum of biological activities [6] [7]. Pyrimidine with its interesting heterocyclic structure has extensively been used in drug design due to its potential antimicrobial, antifungal, antiviral and antitumor properties. Many ligands containing the pyridine ring and their transition metal complexes have been synthesized and tested for biological and therapeutic properties where they sometimes act as models for the active sites of biomolecules [4] [8] [9]. The importance of 2-benzoylpyridine metal complexes, for example, is due to their ability to facilitate substrate binding thus stabilizing the reactive intermediates of transition metals [4] [10].

Copper complexes have recently been the subject of intense research because of their potentials as radiopharmaceuticals for targeting hypoxic tissues [6] and as effective drugs for the treatment of refractory neuroblastoma in children [7]. Copper is an important trace element for plants and animals and is involved in mixed ligand complex formation in a number of biological processes [11]. Many cobalt(II) complexes of Schiff base ligands containing 2-benzoylpyridine behaved as a growth inhibitor for microorganisms [9]. Binuclear copper(II) complexes with monoatomic bridges, such as halides, have attracted recent attention due to their structural diversity and interesting catalytic, magnetic and biological properties [8] [12]. Depending on the nature of the co-ligands, chloride or oxygen bridged compounds, having square planar $\mathrm{Cu}(\mathrm{O})_{2} \mathrm{Cu}$ bridging loops show different molecular structures [13] [14]. The crystalline architectures of these compounds are found to be interesting due to variations in the nature of intervening intermolecular forces.

The presence of the primary amine functionality in heterocyclic compounds containing rings such as pyridine and pyrimidine has prompted researchers to embark on the synthesis of Schiff bases of pyridine derivatives and their metal complexes. Also, Schiff bases easily undergo hydrolysis which is considered to be a very significant reaction in many pharmacological and biological processes resulting in the formation of new species [15] [16]. Recently our group embarks on studies on the biological activities of complexes of heterocyclic Schiff base ligands 
[17]. In this paper we report on the synthesis, characterization and evaluation of the biological activities of binuclear metal complexes of 2-benzoylpyridine $\left(\mathrm{L}_{2}\right)$ and phenyl(pyridin-2-yl)methanediol $\left(\mathrm{L}_{3}\right)$ obtained from the hydrolysis of 1phenyl-1-(pyridin-2-yl)-N-(pyrimidin-2-yl)methanimine dihydrate $\left(\mathrm{L}_{1}\right)$ in the presence of salts of $\mathrm{V}(\mathrm{IV}), \mathrm{Co}(\mathrm{II})$ and $\mathrm{Cu}(\mathrm{II})$.

\section{Experimental}

\subsection{Materials and Methods}

All reagents and solvents were obtained from commercial sources and used as received without any further purification. Microanalysis $(\mathrm{C}, \mathrm{H}$ and $\mathrm{N})$ data were obtained using a Perkin-Elmer automated model 2400 series II CHNS/0 analyzer. Melting points were determined using an analogy-SMP11 melting point measuring instrument of the Stuart Scientific type. The 1D and 2D spectra were recorded at room temperature in DMSO using a Bruker ARX 500 NMR Spectrometer (proton at $600 \mathrm{Mhz}$ and carbon ${ }^{13} \mathrm{C}$ at $150 \mathrm{MHz}$ ). Infrared spectra were recorded using single reflectance ATR spectrometers on $\mathrm{KBr}$ disc. Electronic spectra were obtained using a HACH DR 3900 spectrophotometer. Thermal analyses were carried out using a Perkin-Elmer Pyris 6 TGA type device up to $600^{\circ} \mathrm{C}$. Conductivity measurements were carried out using a Labtech ${ }^{\oplus}$ Digital Conductivity Meter type AVI-846 at room temperature and a cell constant of 1.056. Single crystal X-ray structure determination was carried out using a Rigaku Super Nova diffractometer.

\subsection{Synthesis}

The Schiff base ligand and its complexes were synthesized according to reported general synthetic procedures with some slight modifications [18] [19].

\subsubsection{Synthesis of the Schiff Base ( $\left.\mathrm{L}_{1}\right)$}

To a solution of $10 \mathrm{~mL}$ of methanol containing $0.95 \mathrm{~g}(10 \mathrm{mmol})$ of 2-aminopyrimidine, $1.83 \mathrm{~g}(10 \mathrm{mmol})$ of 2-benzoylpyridine dissolved in $10 \mathrm{~mL}$ of methanol was added. The reaction mixture was maintained under reflux for 4 hours under continuous stirring. The mixture was allowed to cool at room temperature to obtain a pale yellow precipitate which was filtered, washed several times with ethanol and dried in a desiccator.

Yield: 1.60 g (54.05\%), m.p. $64^{\circ} \mathrm{C}-66^{\circ} \mathrm{C}$. Analysis for $\mathrm{C}_{16} \mathrm{H}_{12} \mathrm{~N}_{4} \cdot 2 \mathrm{H}_{2} \mathrm{O}$ (\%) Found (calc): C, 64.92 (64.85); H, 5.00 (5.44); N, 23.00 (18.91).

\subsubsection{Synthesis of Metal (II) Complexes}

All complexes were synthesized by adding $20 \mathrm{~mL}$ of an ethanolic solution of either $\mathrm{VOSO}_{4}(0.326 \mathrm{~g}, 2 \mathrm{mmol}), \mathrm{Co}\left(\mathrm{NO}_{3}\right)_{2} \cdot 6 \mathrm{H}_{2} \mathrm{O}(0.582 \mathrm{~g}, 2 \mathrm{mmol})$ or $\mathrm{Cu}\left(\mathrm{NO}_{3}\right)_{2} \cdot 5 \mathrm{H}_{2} \mathrm{O}$ $(0.554 \mathrm{~g}, 2 \mathrm{mmol})$ to a $30 \mathrm{~mL}$ ethanol-acetone mixture of ( $1.35 \mathrm{~g}, 4 \mathrm{mmol})$ Schiff base $\left(L_{1}\right)$. The final mixtures were stirred at room temperature for about 24 hours to obtained precipitates which were filtered, washed with methanol and dried in a desiccator over calcium chloride. 


\subsection{Crystal Structure Determination}

A suitable single crystal of $\mathrm{C}_{51} \mathrm{H}_{40} \mathrm{Cu}_{2} \mathrm{~N}_{7} \mathrm{O}_{12}$ was mounted on a Rigaku Supernova diffractometer and data were collected using $\mathrm{Mo} \mathrm{Ka}(\lambda=0.71073 \AA)$ radiation at a temperature of $95.01 \mathrm{~K}$. The structure was solved using olex2 [20] with the ShelXT [21] structure solution program using Intrinsic Phasing and refined with the olex2 refine refinement package [20], using Gauss-Newton minimisation.

\subsection{Antimicrobial Study}

The synthesized compounds were used for antimicrobial screening by testing against three bacterial strains (Eschericia coli, Klebsiella pneumonia and Staphylococcus aureus) and three fungal strains, (Candida albicans, Candida glabrata and Candida parapsilosi), Ceftriaxone, Rifampicin and Fluconazole were used as antibacterial and antifungal references respectively.

Antimicrobial studies were carried out using the disc diffusion method based on the determination of the zone of inhibition around the paper discs [22]. In fact, $40 \mathrm{mg}$ of each compound was dissolved in $1 \mathrm{~mL}$ of $10 \%$ DMSO making a final concentration of $40 \mathrm{mg} / \mathrm{mL}$. Discs of wattman $\mathrm{N}^{\circ} 3$ filter paper of $5 \mathrm{~mm}$ in diameter were deposited on the surface of the seeded medium. $10 \mu \mathrm{L}$ of products were then deposited on each corresponding disk and left for pre-diffusion for 15 minutes at room temperature before being incubated at $37^{\circ} \mathrm{C}$ for 24 hours for bacteria and 48 hours for yeasts. The antimicrobial activities were assessed by measuring the diameter of the zone of inhibition of the bacterial and fungal growth around every Disc with a ruler following two axes. For every product tested, three determinations were made.

\subsection{In Vitro Antioxidant Activities}

The synthesized compounds were tested for in vitro antioxidant activities at $37^{\circ} \mathrm{C}$ using free both the radical scavenging assay (DPPH) method and Ferric Ion Reducing Antioxidant Power Assay (FRAP) method.

\subsubsection{DPPH Free Radical Trapping Assay Method}

In this method, the antiradical activity of the ligand $\mathrm{L}_{\mathrm{I}}$ and binuclear metal complexes were tested against the stable free radical of 1, 1-diphenyl-2-picrylhydrazyl (DPPH), using the free radical scavenging assay with some modifications [23]. Solutions of compounds at different concentrations (1000, 500, 250, 125, 62.5, $31.25,15.625$ and $7.8125 \mu \mathrm{g} / \mathrm{mL}$ ) were prepared in methanol as solvent. $25 \mu \mathrm{L}$ of each sample at different concentrations, and $75 \mu \mathrm{L}$ of DPPH (0.02\%) solution were measured into different test tubes and the mixture shaken vigorously for about 30 minutes. The contents of the test tubes were then incubated in the dark for 30 minutes at room temperature. A blank DPPH solution without the sample used for the baseline correction gave a strong absorption maximum at $517 \mathrm{~nm}$ (purple color with $\varepsilon=8.32 \times 10^{3} \mathrm{M}^{-1} \cdot \mathrm{cm}^{-1}$ ). After incubation, the absorbance was determined at wavelength between 510 and $520 \mathrm{~nm}$ for each sample using a UV-visible spectrometer. The test was performed in triplicate using ascorbic acid 
(vitamin C) as positive control. The observed decrease in absorbance values indicate that the compounds show scavenging activity and the relative free radical scavenging activity was calculated using formula 1 below:

$$
\% \text { RSA }=\frac{\text { Ao }- \text { As }}{\text { Ao }} \times 100
$$

where RSA represents the radical Scavenging Activity; Ao is the absorbance of white $(\mathrm{DPPH}+$ methanol) and As is the absorbance of the radical DPPH + compounds.

\subsubsection{Ferric Ion Reducing Antioxidant Power Assay (FRAP)}

In this method, the antiradical power is based on the reduction of $\mathrm{Fe}^{3+}$ to $\mathrm{Fe}^{2+}$ by compounds which, in the presence of 1, 10-phenanthroline, form a brown or orange-red colored complex [24]. The complex absorbs at $505 \mathrm{~nm}$ and the intensity of the coloration is proportional to the amount of $\mathrm{Fe}^{3+}$ converted to $\mathrm{Fe}^{2+}$ by the compound as shown in Scheme 2.

$$
\begin{aligned}
& \left.\left.\mathrm{Fe}^{3+} \text { (oxidant }\right)+\mathrm{e}^{-} \text {(antioxidant }\right) \\
& \leftrightarrow \mathrm{Fe}^{2+}(\text { Reducing agent })+\text { oxidized antioxidant }
\end{aligned}
$$

Solutions of each compound were prepared in methanol. $25 \mu \mathrm{L}$ of each solution were added to a new microplate and $25 \mu \mathrm{L}$ of $\mathrm{Fe}^{3+}$ solution $(1.2 \mathrm{mg} / \mathrm{mL})$ added. The plates were pre-incubated for 15 minutes at room temperature. After this period, $50 \mu \mathrm{L}$ of ortho-phenanthroline $(0.2 \%)$ was added to obtain final concentrations of $1000,500,250,125,62.5,31.25,15.625,7.8125,3.90625$ and $1.95325 \mu \mathrm{g} / \mathrm{mL}$. The reaction mixtures were then incubated for 15 minutes at room temperature and the absorbance measured at $505 \mathrm{~nm}$ using a spectrophotometer. Ascorbic acid was used as a positive control and was treated in the same manner as for the compounds. The test was performed in triplicate. A graph of optical density versus concentration was plotted to the degree of correlation between the concentration of the compounds and their reducing power.

\section{Results and Discussion}

\subsection{Synthesis and Characterization of the Schiff Base $L_{1}$}

The Schiff base $\mathrm{L}_{1}$ was prepared by the condensation of equimolar amounts of 2 -aminopyrimidine with 2-benzoylpyridine in absolute methanol under reflux at $65^{\circ} \mathrm{C}$ as shown in Scheme 1.<smiles>Nc1ncccn1</smiles>

pyrimidin-2-amine

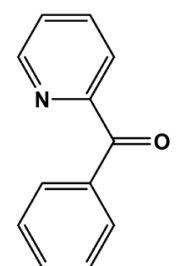

2-benzoylpyridine

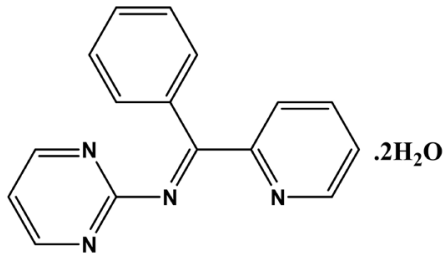

$\mathbf{L}_{\mathbf{I}}$

Scheme 1. Synthesis of 1-phenyl-1-(pyridin-2-yl)-N-(pyrimidin-2-yl)methanimine dihydrate $\left(\mathrm{L}_{1}\right)$. 
The Schiff base is brownish yellow, stable at room temperature, soluble in organic solvents such as methanol, ethanol, DMSO, acetone and DMF. The 1D and 2D NMR sequences were recorded for the characterization of the molecule, in order to provide the structure of the ligand synthesized.

\subsection{Infrared Study of the Schiff Base $\mathrm{L}_{1}$}

The infrared spectrum of the Schiff base is presented in Figure 1. The Infrared spectrum exhibits an intense absorption band at $1643 \mathrm{~cm}^{-1}$ attributed to azomethine group $v_{(\mathrm{C}=\mathrm{N})}$. The very strong absorption band at $1556 \mathrm{~cm}^{-1}$ is attributed to $v_{(\mathrm{C}=\mathrm{N})}$ group of the ring. The band observed at $3326 \mathrm{~cm}^{-1}$ is attributed to $(\mathrm{O}-\mathrm{H})$ vibration mode of water molecules [25]. The loss of the absorption band around $3317-3385 \mathrm{~cm}^{-1}$ attributed to $v_{(\mathrm{N}-\mathrm{H})}$ stretch of 2-aminopyrimidine and at 1706 $\mathrm{cm}^{-1}$ for $v_{(\mathrm{C}=\mathrm{O})}$ of 2-benzoylpyridine and the appearance of a band at $1643 \mathrm{~cm}^{-1}$ attributed to azomethine group $v_{(\mathrm{C}=\mathrm{N})}$ in the ligand, are indicative of the formation of the Schiff base $\mathrm{L}_{1}$.

\section{3. ${ }^{1} \mathrm{H}$ NMR Spectral Analysis of the Schiff Base $\mathrm{L}_{1}$}

The ${ }^{1} \mathrm{H}$-NMR spectrum of the Schiff base $\mathrm{L}_{1}$ is presented in Figure 2 and the ${ }^{1} \mathrm{H}-\mathrm{NMR}$ data of the compounds and the chemical shifts of the different types of protons are listed in Table 1.

Table 1. $\left({ }^{1} \mathrm{H}\right)$ and $\left({ }^{13} \mathrm{C}\right)$ NMR chemical shift data observed for the Schiff base $\left(\mathrm{L}_{1}\right)$.

\begin{tabular}{|c|c|c|c|c|}
\hline $\mathrm{N}^{\bullet} \mathrm{C}$ & ${ }^{13} \mathrm{C}(\delta, \mathrm{ppm})$ & DEPT 135 & ${ }^{1} \mathrm{H}^{*}(\delta, \mathrm{ppm})$ & HMBC \\
\hline 1 & 110.63 & $\mathrm{CH}$ & $6.55(d d, 1 \mathrm{H}$, Pyrim. $)$ & - \\
\hline 2,6 & 158.42 & $\mathrm{CH}$ & 8.23 (d, 2H, Pyrim.) & - \\
\hline 4 & 164.10 & - & - & 2.4 \\
\hline 8 & 164.10 & - & - & - \\
\hline 9 & 154.96 & - & - & 20.9 \\
\hline 10 & 136.48 & - & - & - \\
\hline 11 & 131.07 & & $7.97(m, 1 \mathrm{H}$, Harom. $)$ & \\
\hline 12 & 124.63 & & $8.01(m, 1 \mathrm{H}$, Harom. $)$ & \\
\hline 13 & 128.70 & $\mathrm{CH}$ & 7.55 ( $m, 1 \mathrm{H}$, Harom.) & - \\
\hline 14 & 124.63 & & $8.01(m, 1 \mathrm{H}$, Harom. $)$ & \\
\hline 15 & 131.07 & & 7.97 ( $m, 1 \mathrm{H}$, Harom.) & \\
\hline 17 & 149.05 & & $8.74(d, 1 \mathrm{H}$, Pyr. $)$ & \\
\hline 18 & 127.22 & & $7.68(t, 1 \mathrm{H}, \mathrm{Pyr})$. & \\
\hline 19 & 133.47 & $\mathrm{CH}$ & $7.68(t d, 1 \mathrm{H}, \mathrm{Pyr})$. & - \\
\hline 20 & 138.47 & & $8.08(d, 1 \mathrm{H}, \mathrm{Pyr})$. & \\
\hline- & - & $\mathrm{H}_{2} \mathrm{O}$ & $3.36\left(\mathrm{~s}, 2 \mathrm{H}_{2} \mathrm{O}\right)$ & \\
\hline
\end{tabular}




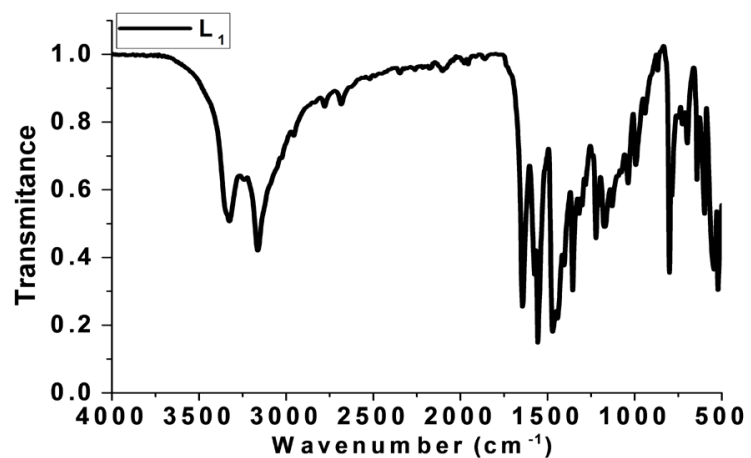

Figure 1. Infrared spectrum of the Schiff base ligand $\mathrm{L}_{1}$.

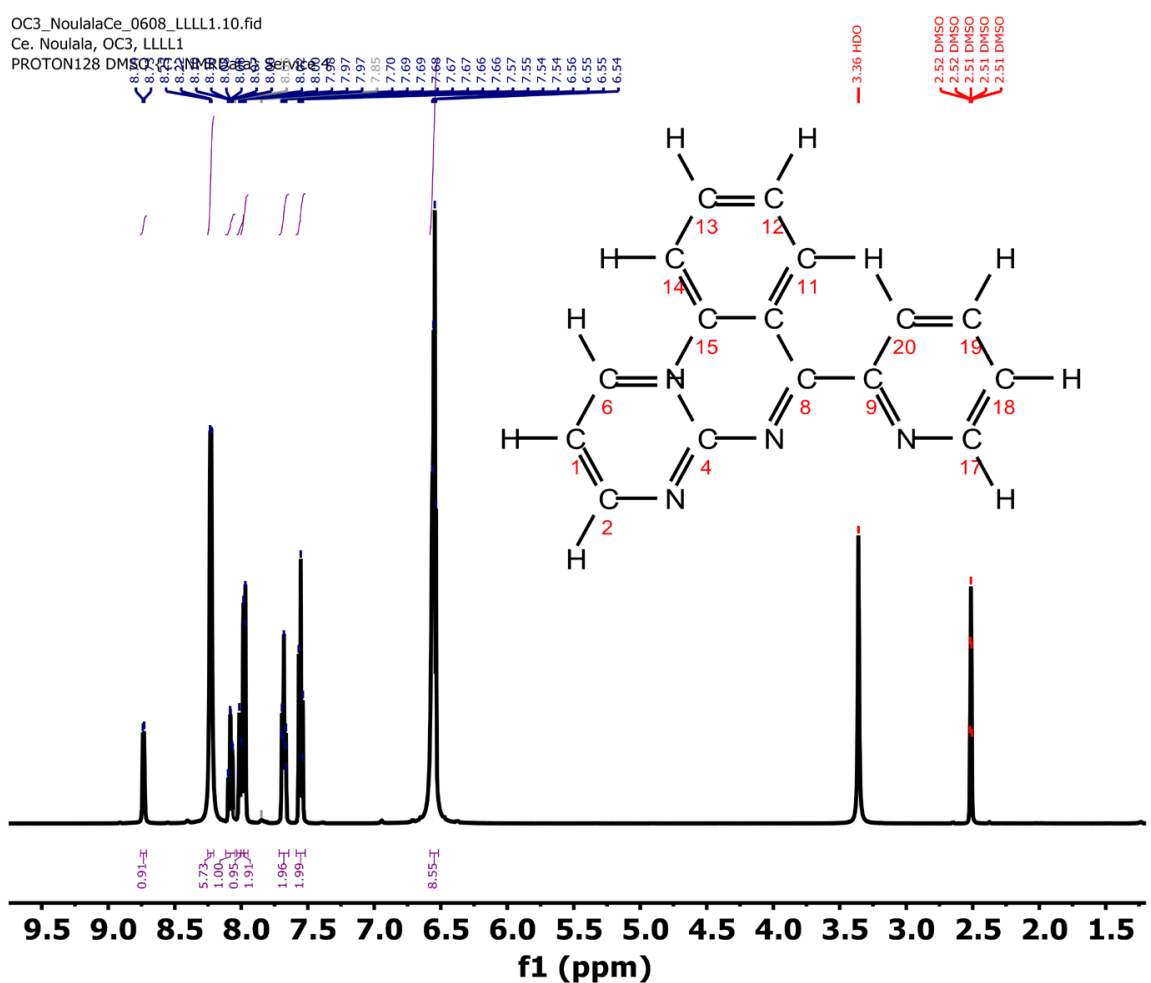

Figure 2. ${ }^{1} \mathrm{H}-\mathrm{NMR}$ spectrum of the Schiff base ligand $\mathrm{L}_{1}$.

Examination of the proton NMR spectrum shows the presence of three doublets. The first at $\delta=8.08 \mathrm{ppm}$ is attributed to the proton $\mathrm{H}-20$; the second at $\delta=$ $8.23 \mathrm{ppm}$ is attributed to the protons of the $\mathrm{H}-2, \mathrm{H}-6$ group of the pyrimidine ring and the third at $\delta=8.74 \mathrm{ppm}$ is attributed to the $\mathrm{H}-17$ proton of the pyridine ring. This spectrum also contains a signal in the form of doublet of a doublet at $\delta=6.55 \mathrm{ppm}$ attributable to the proton at position $\mathrm{C}-1$. The spectrum also shows doublet of a triplet corresponding to the proton $\mathrm{H}-19$ at $\delta=7.68$. The protons of the aromatic nucleus $(\mathrm{H}-11, \mathrm{H}-12, \mathrm{H}-13, \mathrm{H}-14$ and $\mathrm{H}-15)$ are represented by the presence of multiplets between $\delta=7.97-8.01 \mathrm{ppm}$.

\section{4. ${ }^{13}$ C NMR Spectral Analysis of the Schiff Base $L_{1}$}

Analysis of the ${ }^{13} \mathrm{C}$-NMR spectra (Figure 3 ) shows twelve distinguished carbon 
families. The two signals at $\delta=158.42$ and $\delta=110.63 \mathrm{ppm}$ correspond to the C-2, C- 6 and C- 1 carbons. Signals around $\delta=127.22-133.47$ have been attributed to the carbons of the aromatic and pyridine rings. The spectrum obtained using the DEPT sequence (Figure 4) identified clearly four quaternary carbons. The quaternary carbon signal at $\delta=164,11$ at $\mathrm{C}-8$ suggests the presence of the imine function. The signals were also observed at $\delta=164.11 \mathrm{ppm}$ and $\delta=154.96$ ppm, corresponding to the carbon at C-4 and C-9 of the pyrimidine and pyridine ring. Another signal at $\delta=136.48$ corresponding to the $\mathrm{C}-10$ carbon of the aromatic ring. All the data result of ${ }^{13} \mathrm{C}-\mathrm{NMR}$ analysis is summarize in Table 1.

\subsection{COSY and NOESY Spectra Analysis}

COSY and NOESY are 2D homonuclear correlation techniques for microstructure determination. COSY or Correlation spectroscopy correlates chemical shift of two hydrogen nuclei located on two different carbons that are separated by a single bond via J coupling. Heteronuclear Single-Quantum Correlation Spectroscopy (HSQC) determines the correlations between two different types of nuclei (commonly ${ }^{1} \mathrm{H}$ with ${ }^{13} \mathrm{C}$ or ${ }^{15} \mathrm{~N}$ ), which are separated by one bond. NOESY or Nuclear overhauser effect spectroscopy measures the cross-relaxation rates of spins that are close to one another in space. Heteronuclear multiple-bond correlation spectroscopy (HMBC) detects heteronuclear correlations over longer ranges of about $2-4$ bonds [26].

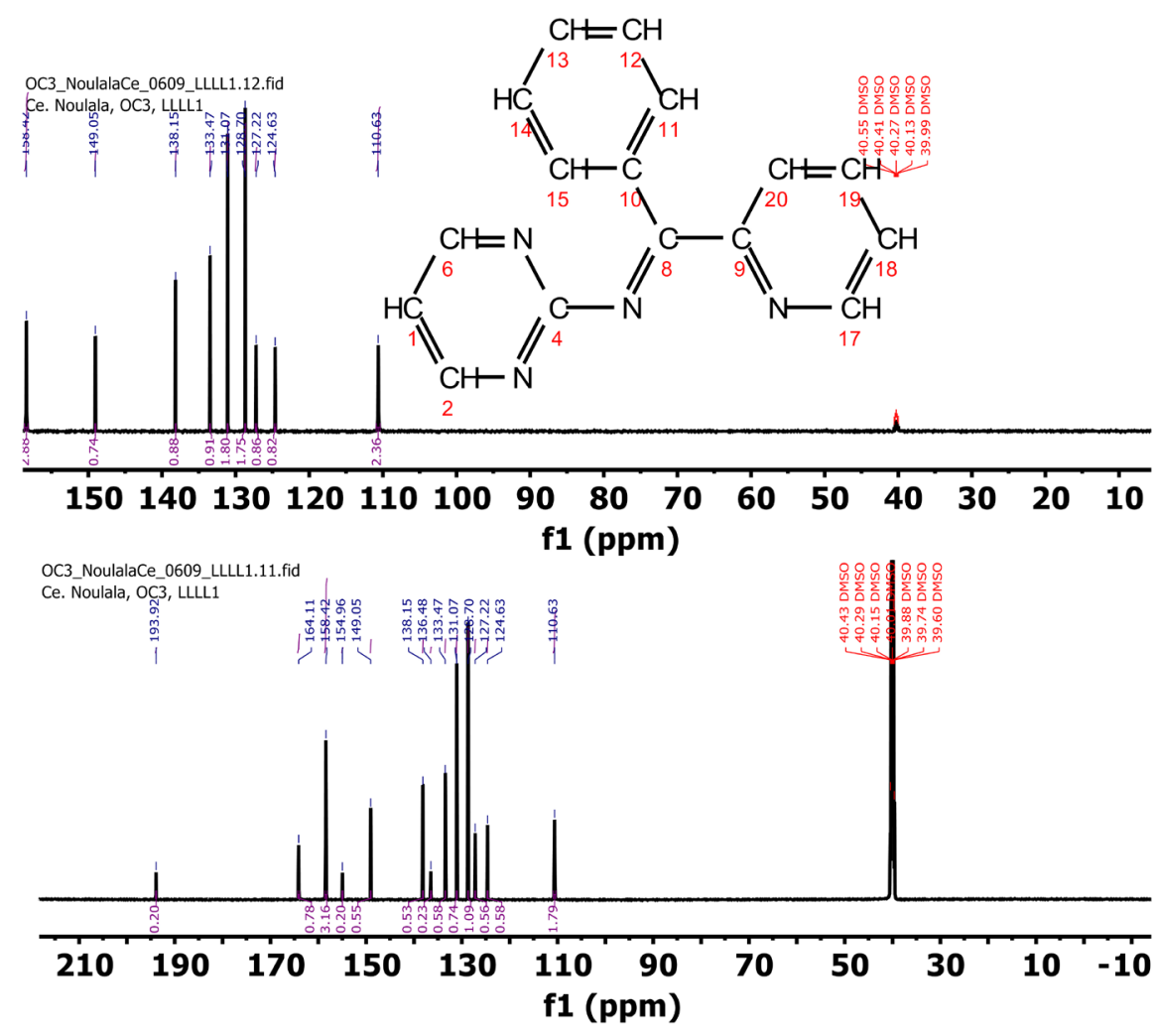

Figure 3. Comparison of ${ }^{13} \mathrm{C}-\mathrm{NMR}$ spectrum with the ${ }^{13} \mathrm{C}-\mathrm{NMR}$ spectrum in DEPT mode. 


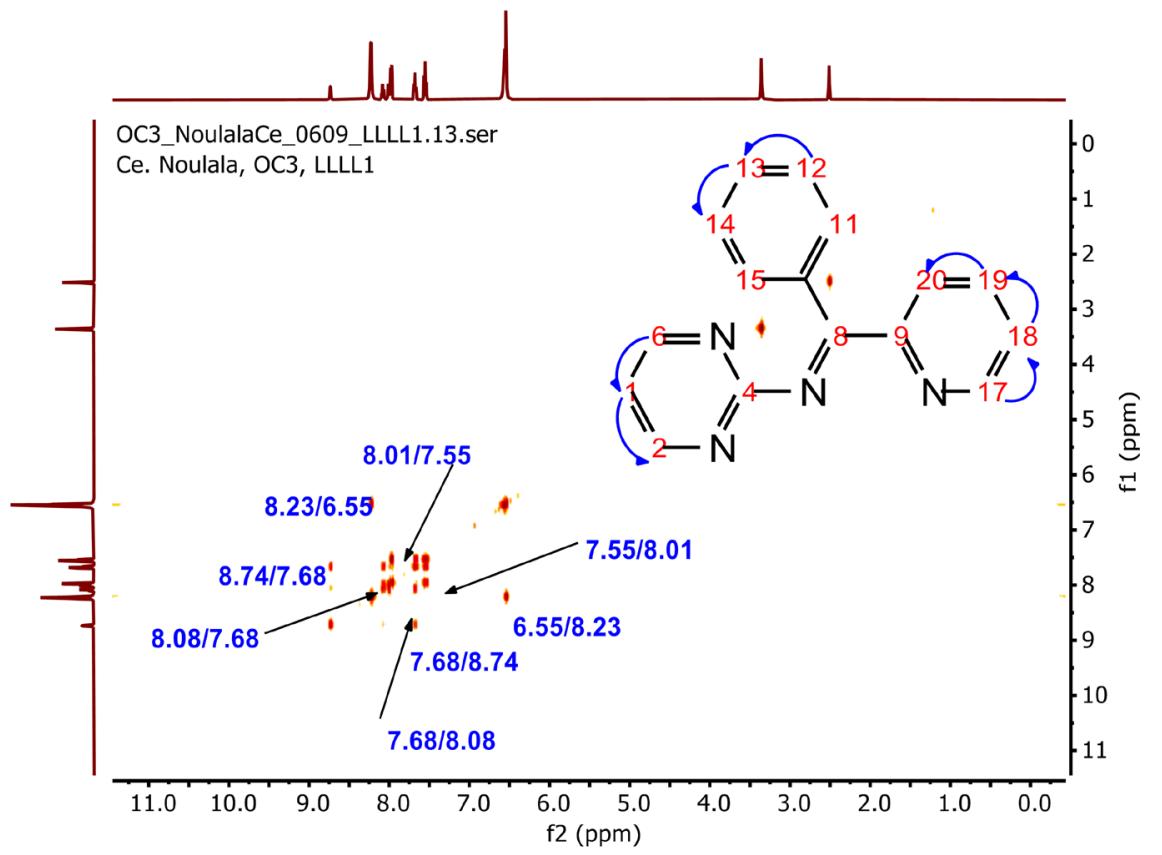

(a)

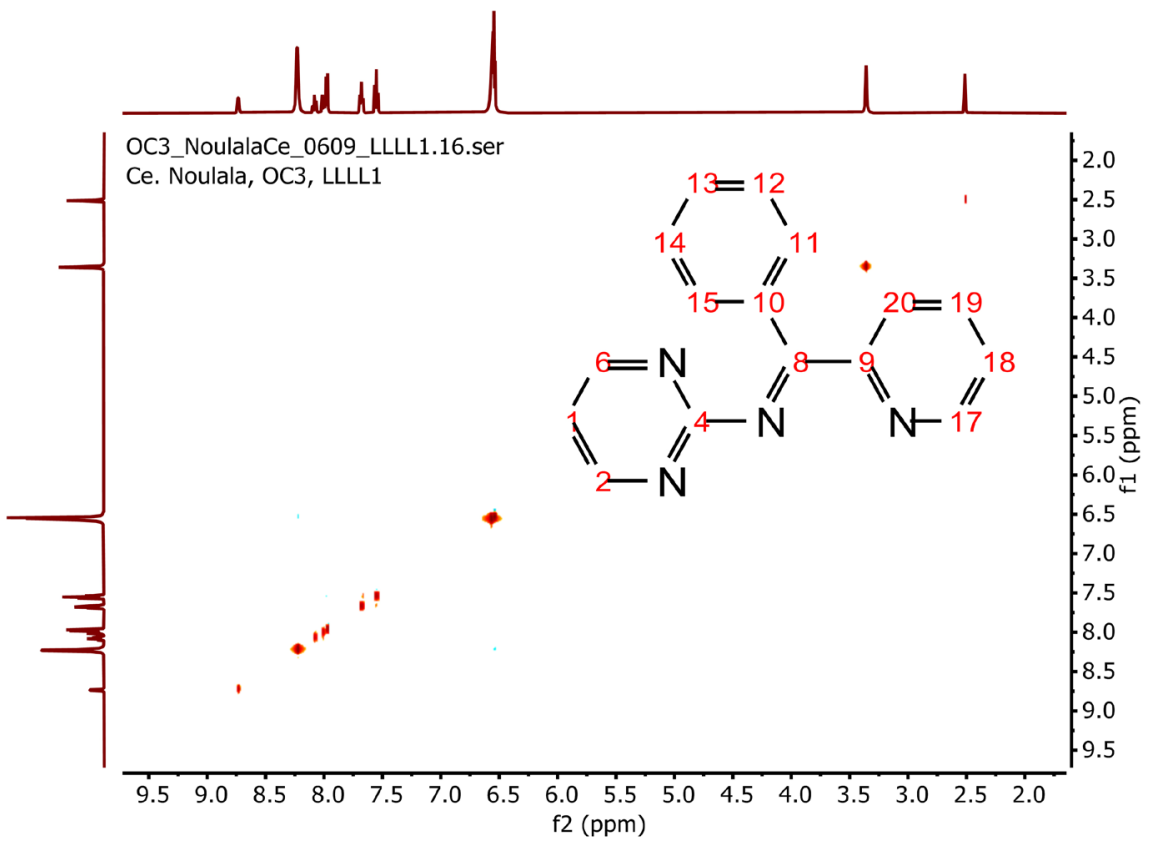

(b)

Figure 4. (a) COSY and (b) NOESY correlations of Schiff base $\mathrm{L}_{1}$.

An examination of the COSY spectrum (Figure 4(a)) shows a correlation between the $\mathrm{H}-1$ nucleus $(\delta=6.55 \mathrm{ppm})$ and the $\mathrm{H}-2, \mathrm{H}-6$ proton $(\delta=8.23 \mathrm{ppm})$ of the pyrimidine ring. On the same spectrum, a correlation is observed between the proton $\mathrm{H}-12(\delta=8.01 \mathrm{ppm})$ and its neighbour $\mathrm{H}-13(\delta=7.55 \mathrm{ppm})$. This spectrum also shows correlation between the $\mathrm{H}-17, \mathrm{H}-20$ nuclei of pyridine with the protons $\mathrm{H}-18, \mathrm{H}-19$. 
All protons and carbons were assigned after analysis of the HSQC and HMBC (Figure 5) spectra and the data results are summarizing in Table 1.

HSQC spectrum (Figure 5(a)) makes it possible to locate C-1 and C-2, C-6 at $\delta=110.63 \mathrm{ppm}$ and $\delta=158.42 \mathrm{ppm} ; \mathrm{C}-18, \mathrm{C}-19$ at $\delta=127.22$ and $\delta=133.47$ ppm; C-12 at $\delta=124.63 \mathrm{ppm}$; C-13 at $\delta=128.07 \mathrm{ppm}$; C-20 at $\delta=138.47 \mathrm{ppm}$; $\mathrm{C}-17$ at $\delta=149.05 \mathrm{ppm}$; $\mathrm{C}-11, \mathrm{C}-15$ at $\delta=131.07 \mathrm{ppm}$.

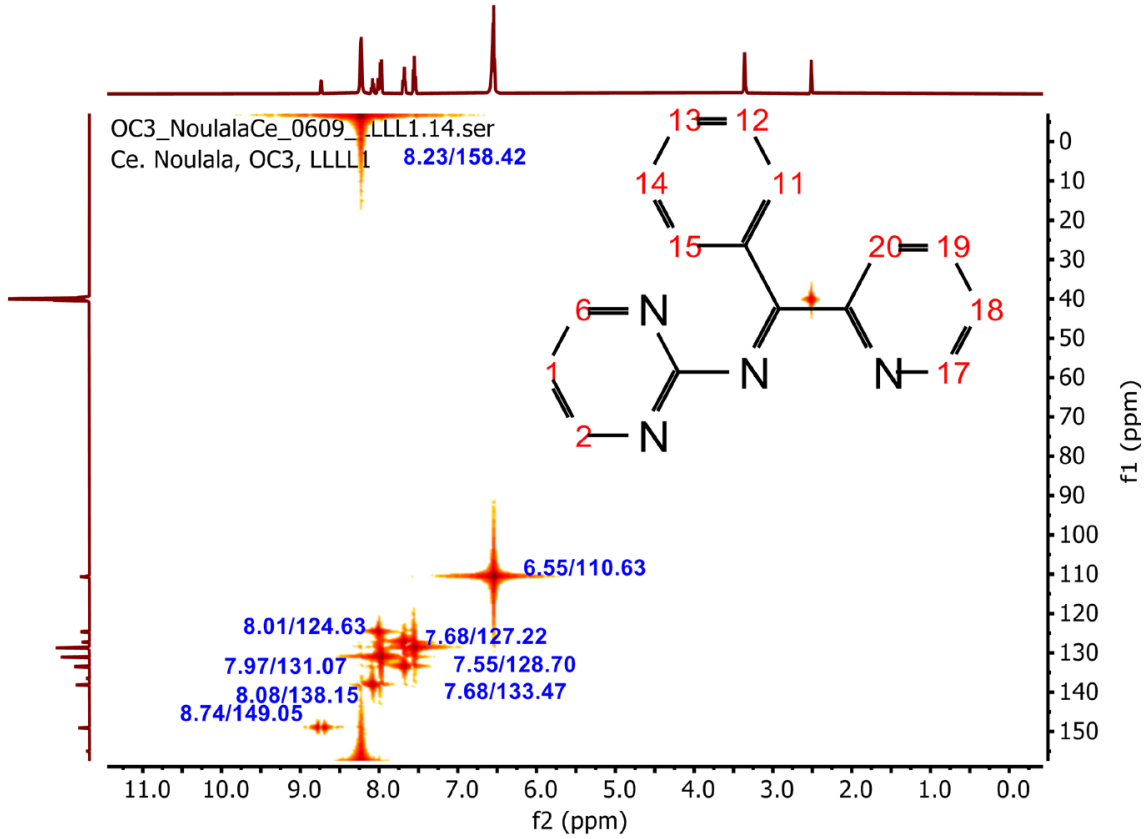

(a)

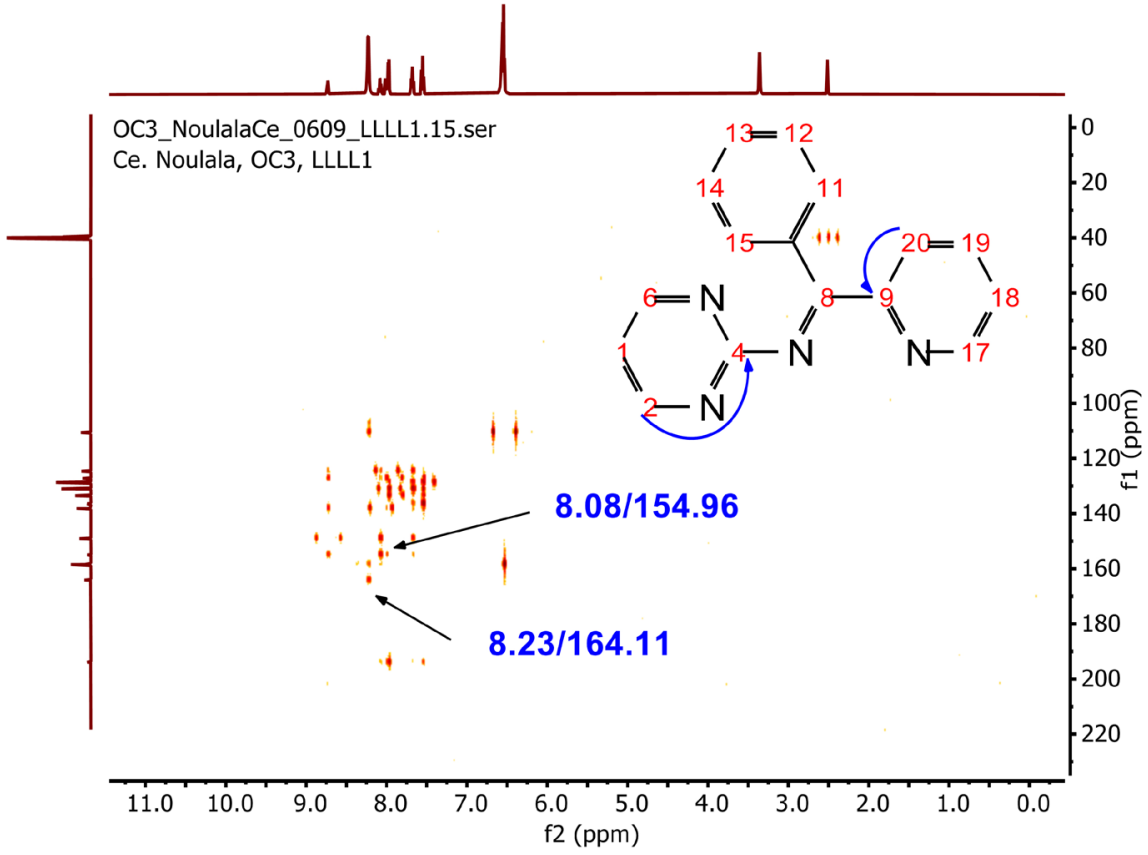

(b)

Figure 5. (a) HSQC correlations of the Schiff base $\left(\mathrm{L}_{1}\right)$; (b) HMBC correlations of the Schiff base $\left(\mathrm{L}_{1}\right)$ showing the different of HMBC correlations. 
HMBC spectrum (Figure 5(b)) shows correlation of the $\mathrm{H}-1$ proton with the quaternary carbon of the imine function at $\delta=164.11 \mathrm{ppm}$, which allows the attribution of the latter to the C-7 carbon. The same spectrum also shows a correlation of proton $\mathrm{H}-11$ with carbon at $\delta=154.96 \mathrm{ppm}$ which can only be C-9 and another correlation of proton $\mathrm{H}-15$ with oxygenated carbon at $\delta=193.92 \mathrm{ppm}$ attributed to C-5. Proton H-15 with the oxygenated carbon at $\delta=193.92 \mathrm{ppm}$ attributed to C-5 [26].

The analysis of all the IR and NMR data confirm the proposed structure of the Schiff base ligand $\left(\mathrm{L}_{1}\right)$ as shown in Scheme 3 .

\section{Synthesis and Characterization of Metal Complexes of the Schiff Base $\mathrm{L}_{1}$}

The Schiff base $\left(\mathrm{L}_{1}\right)$ was reacted with metal salts in a 1:2 molar ratio in an attempt to synthesized vanadium(IV), cobalt(II) and copper(II) complexes of the form, $\left[M\left(L_{1}\right)_{2}\right]$ following Scheme 2.

The reaction of 1-phenyl-1-(pyridin-2-yl)-N-(pyrimidin-2-yl)methanimine dihydrate $\left(\mathrm{L}_{1}\right)$ with salts of $\mathrm{V}(\mathrm{IV})$, and $\mathrm{Co}$ (II) $\mathrm{Cu}(\mathrm{II})$, however resulted in the hydrolysis of $\mathrm{L}_{1}$ to give binuclear metal complexes of 2-benzoylpyridine $\left(\mathrm{L}_{2}\right)$ and phenyl(pyridin-2-yl)methanediol $\left(\mathrm{L}_{3}\right)$ as revealed by the various analysis, suggesting metal assisted hydrolysis of the Schiff base ligand, $\mathrm{L}_{1}$ during complexation as illustrated in Scheme 3.

We obtained suitable crystals for $\left.\left[\mathrm{Cu}_{2}\left(\mathrm{~L}_{2}\right)_{2}\left(\mathrm{~L}_{3}\right)_{2}\right)\right]$ for single crystal $\mathrm{x}$-ray structure determination. The structure of this [27] and similar compounds [28], obtained by different synthetic procedures (the reactions of 2-benzoylpyridine with copper(II) ion [27] and metal assisted hydrolysis of N'-[(E)-phenyl(pyridin-2-yl) methylidene]furan-2-carbohydrazide [28]) have however been reported elsewhere. The analysis and physical properties of the prepared compounds are given in Table 2.

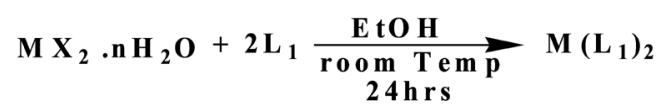

Scheme 2. Equation reaction of the synthesis of $\left[M\left(L_{1}\right)_{2}\right]$ complexes.

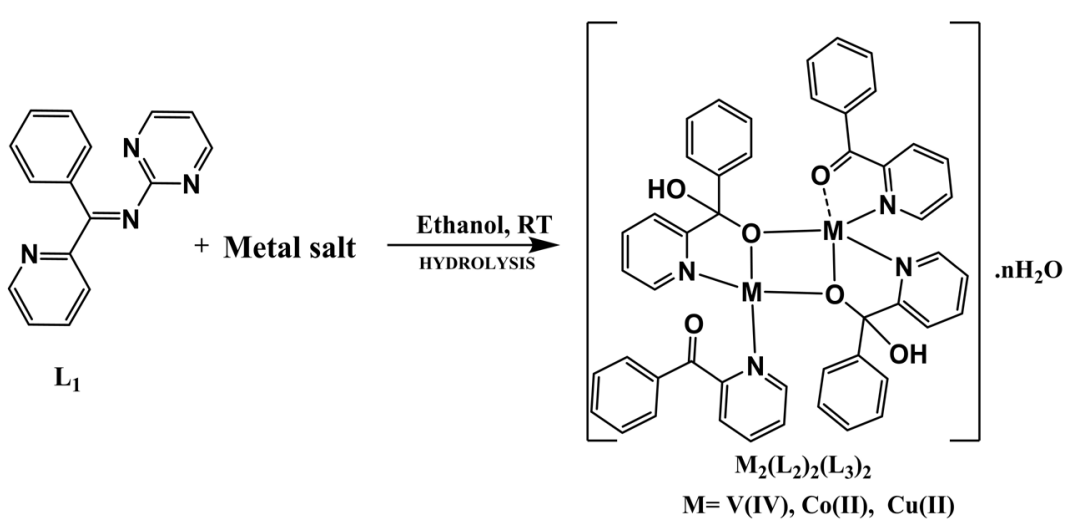

Scheme 3. Reaction equation for the synthesis of binuclear M(II) complexes. 
Table 2. Analysis and physical properties of Schiff base and binuclear $\mathrm{Cu}(\mathrm{II})$ complex.

\begin{tabular}{|c|c|c|c|c|c|c|c|c|}
\hline \multirow{2}{*}{ Compounds } & \multirow{2}{*}{ Empirical formula } & \multirow{2}{*}{$\begin{array}{l}\mathrm{Mol} \cdot \mathrm{Wt} \\
(\mathrm{g} / \mathrm{mol})\end{array}$} & \multirow{2}{*}{ Aspect } & \multirow{2}{*}{$\begin{array}{l}\text { M.p } \\
\left({ }^{\circ} \mathrm{C}\right)\end{array}$} & \multirow{2}{*}{$\begin{array}{c}\text { Yield } \\
(\%)\end{array}$} & \multicolumn{3}{|c|}{$\begin{array}{c}\text { Elemental analysis (\%) } \\
\text { Calc (Exp) }\end{array}$} \\
\hline & & & & & & $\% \mathrm{C}$ & $\% \mathrm{H}$ & $\% \mathrm{~N}$ \\
\hline $\mathrm{L}_{1}$ & $\mathrm{C}_{16} \mathrm{H}_{12} \mathrm{~N}_{4} \cdot 2 \mathrm{H}_{2} \mathrm{O}$ & 296.33 & Brownish Yellow & 64 & 54.48 & $64.85(64.92)$ & $5.44(5.00)$ & $18.91(23.00)$ \\
\hline$\left[\mathrm{Cu}_{2}\left(\mathrm{~L}_{2}\right)_{2}\left(\mathrm{~L}_{3}\right)_{2}\right]$ & $\mathrm{C}_{51} \mathrm{H}_{40} \mathrm{Cu}_{2} \mathrm{~N}_{7} \mathrm{O}_{12}$ & 1081.03 & Greenish crystal & 124 & 55.16 & $55.55(53.42)$ & $4.47(3.83)$ & $7.77(8.44)$ \\
\hline$\left[\mathrm{VO}_{2}\left(\mathrm{~L}_{2}\right)_{2}\right]$ & $\mathrm{VO}_{2}\left(\mathrm{C}_{12} \mathrm{H}_{9} \mathrm{NO}\right)_{2}\left(\mathrm{SO}_{4}\right)_{2} \cdot\left(\mathrm{H}_{2} \mathrm{O}\right)_{3}$ & 746.46 & $\begin{array}{c}\text { Yellowish } \\
\text { green powder }\end{array}$ & $\geq 360$ & 39.10 & $38.62(38.43)$ & $3.24(3.01)$ & $3.75(3.12)$ \\
\hline$\left[\mathrm{Co}_{2}\left(\mathrm{~L}_{2}\right)\left(\mathrm{L}_{3}\right)_{2}\right]$ & $\begin{array}{c}{\left[\mathrm{Co}_{2}\left(\mathrm{C}_{12} \mathrm{H}_{9} \mathrm{NO}\right)\right.} \\
\left.\left(\mathrm{C}_{12} \mathrm{H}_{10} \mathrm{NO}_{2}\right)_{2}\left(\mathrm{H}_{2} \mathrm{O}\right)\right]\left(\mathrm{NO}_{3}\right)_{2}\end{array}$ & 905.54 & Pink powder & 202 & 50.33 & $47.75(48.54)$ & $4.45(3.88)$ & $9.28(9.71)$ \\
\hline
\end{tabular}

Elemental analysis values for the Schiff base and Metal(II) complexes (Table 2) tallied with the expected values, thus confirming the purity and proposed formulation of the Schiff base ligand and its complexes.

\subsection{Infrared Study of the Binuclear Metal(II) Complexes}

The IR spectrum of the ligand when compared to that the of M(II) complexes reveals the binding of the ligands, $\mathrm{L}_{2}$ and $\mathrm{L}_{3}$ to $\mathrm{M}(\mathrm{II})$ ions. In the spectra of the complexes (Figure 6) and IR data (Table 3), the disappearance of the strong band observed for the free ligand at $1643 \mathrm{~cm}^{-1}$ and attributed to the imine group $v_{(\mathrm{C}=\mathrm{N})}$, and the appearance of a new band around $1768-1668 \mathrm{~cm}^{-1}$ attributed to the carbonyl group, $v_{(\mathrm{C}=0)}$ are indicative of the hydrolysis of the Schiff base $\mathrm{L}_{1}$ and the formation of 2-benzoylpyridine $\mathrm{L}_{2}$ [29] [30]. The strong absorption band at $1556 \mathrm{~cm}^{-1}$ attributed to $v_{(\mathrm{C}=\mathrm{N})}$ group of the pyridyl ring is shifted to the higher values around $1630-1598 \mathrm{~cm}^{-1}$ in the spectra of complexes, suggesting the coordination of the nitrogen of the pyridine ring to the metal centre. The band at $1329 \mathrm{~cm}^{-1}$ in the spectra of the $\mathrm{Cu}(\mathrm{II})$ and $\mathrm{Co}(\mathrm{II})$ complexes is attributed to $v_{(\mathrm{C}-\mathrm{O})}$ of phenyl(pyridin-2-yl)methanediol $\left(\mathrm{L}_{3}\right)$. This is confirm by the presence of a broad band around $3350-3292 \mathrm{~cm}^{-1}$ attributed to hydroxyl group $v_{(\mathrm{O}-\mathrm{H})}$ of phenyl(pyridin-2-yl)methanediol $\left(\mathrm{L}_{3}\right)$ and crystal water molecules [31]. The bands appearing at lower frequencies around $594-454$ and $595-548 \mathrm{~cm}^{-1}$ have been attributed to $v_{(\mathrm{M}-\mathrm{N})}$ and $v_{(\mathrm{M}-\mathrm{O})}$ respectively [32]. Important IR vibrations and corresponding assignments of the $\mathrm{L}_{1}$ ligand and $\mathrm{M}(\mathrm{II})$ complexes have been presented in Table 3.

\subsection{Conductivity Measurement}

The molar conductivities of the complexes were determined in methanol for $\left[(\mathrm{VO})_{2}\left(\mathrm{~L}_{2}\right)_{2}\right]$ and $\left[\mathrm{Co}_{2}\left(\mathrm{~L}_{2}\right)\left(\mathrm{L}_{3}\right)_{2}\right]$ and in ethanol for $\left[\mathrm{Cu}_{2}\left(\mathrm{~L}_{2}\right)_{2}\left(\mathrm{~L}_{3}\right)_{2}\right]$ and the obtained values are summarized in Table 4 . The low value of the molar conductivity $\left(18.25 \mathrm{~S} \cdot \mathrm{mol}^{-1} \cdot \mathrm{cm}^{2}\right)$ for $\left[(\mathrm{VO})_{2}\left(\mathrm{~L}_{2}\right)_{2}\right]$, indicated its molecular nature. While the high values of the molar conductivities for $\left[\mathrm{Cu}_{2}\left(\mathrm{~L}_{2}\right)_{2}\left(\mathrm{~L}_{3}\right)_{2}\right]\left(204.34 \mathrm{~S} \cdot \mathrm{mol}^{-1} \cdot \mathrm{cm}^{2}\right)$ and $\left[\mathrm{Co}_{2}\left(\mathrm{~L}_{2}\right)\left(\mathrm{L}_{3}\right)_{2}\right]\left(295.45 \mathrm{~S} \cdot \mathrm{mol}^{-1} \cdot \mathrm{cm}^{2}\right)$ indicate that they are 1: 2 and 1:3 electrolytes in solution respectively [33] [34]. 


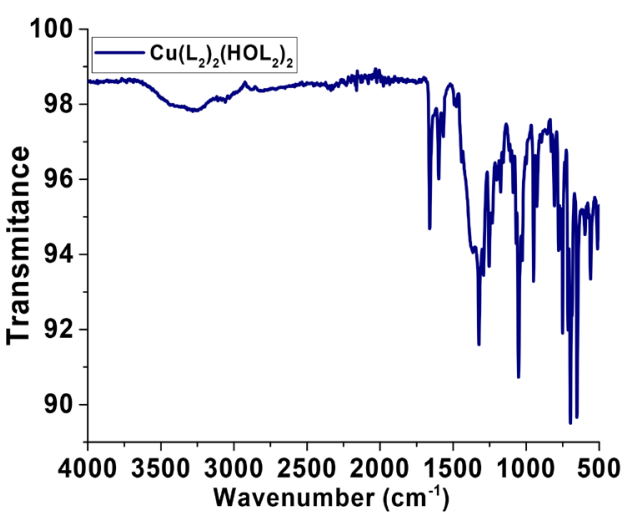

(a)

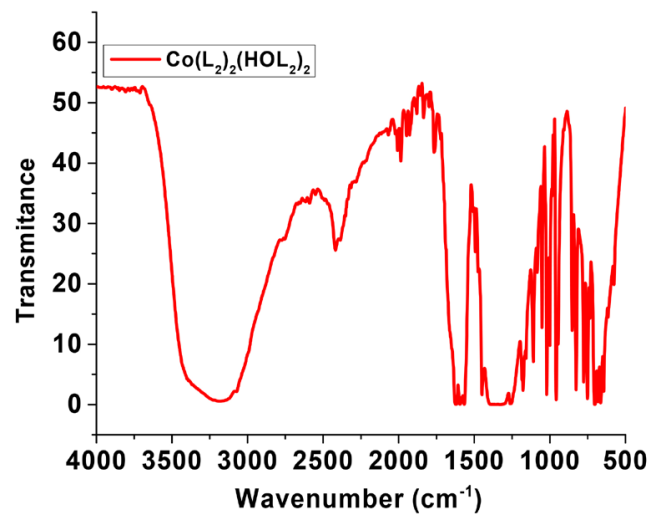

(b)

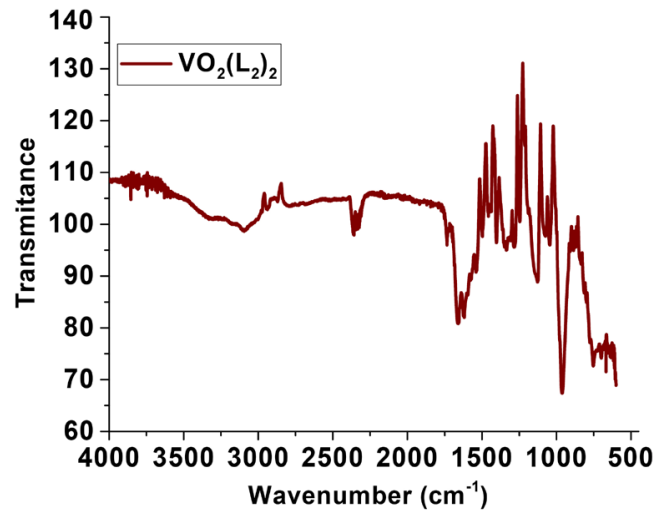

(c)

Figure 6. Infrared spectra of the (a) $\left[\mathrm{Cu}_{2}\left(\mathrm{~L}_{2}\right)_{2}\left(\mathrm{~L}_{3}\right)_{2}\right]$, (b) $\left[\mathrm{Co}_{2}\left(\mathrm{~L}_{2}\right)\left(\mathrm{L}_{3}\right)_{2}\right]$ and (c) $\left[\left(\mathrm{VO}_{2}\right)\left(\mathrm{L}_{2}\right)_{2}\right]$ binuclear complexes.

Table 3. Infrared data of the Schiff base $\left(\mathrm{L}_{1}\right)$ and $\mathrm{M}(\mathrm{II})$ complex.

\begin{tabular}{cccccccccc}
\hline Compound & $v_{(\mathrm{C}=\mathrm{N})}$ & $v_{(\mathrm{C}=\mathrm{Npyr})}$ & $v_{(\mathrm{NH} 2)}$ & $v_{\mathrm{OH}(\mathrm{H} 2 \mathrm{O})}$ & $v_{(\mathrm{C}=\mathrm{O})}$ & $v_{(\mathrm{C}-\mathrm{O})}$ & $v_{(\mathrm{NO} 3)}$ & $v_{(\mathrm{M}-\mathrm{N})}$ & $v_{(\mathrm{M}-\mathrm{O})}$ \\
\hline $\mathrm{L}_{1}$ & 1643 & 1560 & 3326 & $3330-3163$ & - & - & - & - & - \\
{$\left[\mathrm{Cu}_{2}\left(\mathrm{~L}_{2}\right)_{2}\left(\mathrm{~L}_{3}\right)_{2}\right]$} & $/$ & 1598 & $/$ & $3292-3292$ & 1668 & 1329 & 1254 & 454 & 548 \\
{$\left[\mathrm{Co}_{2}\left(\mathrm{~L}_{2}\right)_{2}\left(\mathrm{~L}_{3}\right)_{2}\right]$} & $/$ & 1590 & $/$ & $3292-3350$ & 1768 & 1355 & 1254 & 451 & 510 \\
{$\left[(\mathrm{VO})_{2}\left(\mathrm{~L}_{2}\right)_{2}\right]$} & $/$ & 1642 & $/$ & $3321-3274$ & 1728 & 1322 & - & 594 & 595 \\
\hline
\end{tabular}


Table 4. Assignments of the electronic spectra of $\mathrm{L}_{1}$ ligand and its complexes.

\begin{tabular}{ccccc}
\hline Compound & $\begin{array}{c}\text { Bande Positions } \\
\left(v \text { en } \mathrm{cm}^{-1}\right)\end{array}$ & Assignments & Geometries & $\begin{array}{c}\text { Molar } \\
\text { conductivity } \\
\mathrm{S} \cdot \mathrm{mol}^{-1} \cdot \mathrm{cm}^{2}\end{array}$ \\
\hline $\mathrm{L}_{\mathrm{I}}$ & 21740 & $\pi \rightarrow \pi^{*}$ & - & - \\
{$\left[(\mathrm{VO})_{2}\left(\mathrm{~L}_{2}\right)_{2}\right]$} & 28248 & MLCT & Square pyramidal & 18.25 \\
{$\left[\mathrm{Co}_{2}\left(\mathrm{~L}_{2}\right)\left(\mathrm{L}_{3}\right)_{2}\left(\mathrm{H}_{2} \mathrm{O}\right)\right]\left(\mathrm{NO}_{3}\right)_{3}$} & 21362 & MLCT & Square pyramidal & 295.45 \\
{$\left[\mathrm{Cu}_{2}\left(\mathrm{~L}_{2}\right)_{2}\left(\mathrm{~L}_{3}\right)_{2}\right]\left(\mathrm{NO}_{3}\right)_{2} \cdot \mathrm{H}_{2} \mathrm{O}$} & 13869 & ${ }^{2} \mathrm{~B}_{1 \mathrm{~g}} \rightarrow{ }^{2} \mathrm{~A}_{1 \mathrm{lg}}$ & $\begin{array}{c}\text { Distorted square } \\
\text { planar }\end{array}$ & 204.34 \\
\hline
\end{tabular}

\subsection{UV-Visible Spectroscopy}

The electronic spectral data for the compounds are summarized in Table 4. High intensity bands appeared in the ultraviolet and near-visible regions at 382 and $460 \mathrm{~nm}$ in the spectrum of ligand $\mathrm{L}_{\mathrm{I}}$ and was assigned to the $n \rightarrow \pi^{*}$ transition.

In the spectrum of the $\left[(\mathrm{VO})_{2}\left(\mathrm{~L}_{2}\right)_{2}\right]$ complex, the band appearing in the ultraviolet region at $354 \mathrm{~nm}$ is attributed to the MLCT, which suggests a square-based pyramidal geometry of the complex [34] [35] [36]. The UV-visible spectrum of the Cobalt complex show two bands at 357 and $468 \mathrm{~nm}$ attributed to the MLCT with square pyramidal geometry around cobalt ion [35]. The spectrum of the $\left[\mathrm{Cu}_{2}\left(\mathrm{~L}_{2}\right)_{2}\left(\mathrm{~L}_{3}\right)_{2}\right]$ complex (Figure 7) shows a band at $721 \mathrm{~nm}$ attributed to ligand-metal charge transfer [37].

\subsection{Thermogravimetric Analysis of the Binuclear Copper (II) Complex}

The differential and thermogravimetric analyses of the $\left.\left[\mathrm{Cu}_{2}\left(\mathrm{~L}_{2}\right)_{2}\left(\mathrm{~L}_{3}\right)_{2}\right)\right]$ complex was determined under an inert atmosphere in the range $0^{\circ} \mathrm{C}$ and $600^{\circ} \mathrm{C}$. The thermogram for the $\left[\mathrm{Cu}_{2}\left(\mathrm{~L}_{2}\right)_{2}\left(\mathrm{~L}_{3}\right)_{2}\right]$ is represented in Figure 8. The thermal decomposition curves of $\mathrm{Cu}(\mathrm{II})$ complex showed three steps decomposition. The first step between $30^{\circ} \mathrm{C}$ and $151^{\circ} \mathrm{C}$ corresponds to the loss of a water molecule and an ethanolate ion (Found: 5.36\%; Calc: 5.65\%). The second step between $151^{\circ} \mathrm{C}$ and $180^{\circ} \mathrm{C}$ (found: $6.19 \%$; calc: $6.48 \%$ ) corresponding to the loss of a nitrate ion. While the third decomposition step between $180^{\circ} \mathrm{C}$ and $310^{\circ} \mathrm{C}$ corresponds to the loss of the organic moieties $\left(2 \mathrm{C}_{12} \mathrm{H}_{9} \mathrm{NO}\right.$ and $\left.\mathrm{C}_{12} \mathrm{H}_{10} \mathrm{NO}_{2}\right)$ (found: $62.28 \%$; calc: $63.75 \%$ ) leaving a residue which corresponds to a mixture of copper oxides, $\mathrm{CuO} \cdot \mathrm{Cu}_{2} \mathrm{O}$ (found: $22.5 \%$; calc. $20.6 \%$ ).

\subsection{Crystal Structure of the Binuclear Copper Complex}

Suitable crystals of $\mathrm{Cu}(\mathrm{II})$ complex were obtained for single crystal $\mathrm{x}$-ray structure determination. Table 5 presents the crystal data and refinement parameters. Table 6 lists the selected bond lengths and bond angles. The binuclear complexes are presumed to occur as a result of bridging between the two Metal(II) centers through the deprotonated gem-diol oxygen atoms. The structure of the $\mathrm{Cu}$ (II) complex has however been reported elsewhere [27] [28], even though obtained 
by different synthetic procedures involving the reactions of 2-benzoylpyridine with copper(II) ion [27] and metal assisted hydrolysis of $\mathrm{N}^{\prime}$-[(E)-phenyl(pyridine-2-yl)methylidene]furan-2-carbohydrazide [28].

Table 5. Crystal Data and structure refinement for $\left[\mathrm{Cu}_{2}\left(\mathrm{~L}_{2}\right)_{2}\left(\mathrm{~L}_{3}\right)_{2}\right]\left(\mathrm{NO}_{3}\right)_{2} \mathrm{H}_{2} \mathrm{O} \cdot \mathrm{CH}_{3} \mathrm{CH}_{2} \mathrm{O}$.

\begin{tabular}{|c|c|}
\hline Empirical formula & $\mathrm{C}_{51} \mathrm{H}_{40} \mathrm{Cu}_{2} \mathrm{~N}_{7} \mathrm{O}_{12}$ \\
\hline Formula weight & 1081.04 \\
\hline Temperature/K & $95.01(10)$ \\
\hline Crystal system & monoclinic \\
\hline Space group & $\mathrm{P} 2{ }_{1} / \mathrm{n}$ \\
\hline $\mathrm{a} / \AA$ & $18.3200(4)$ \\
\hline $\mathrm{b} / \AA$ & $13.9885(4)$ \\
\hline$c / \AA$ & $18.6759(5)$ \\
\hline$\alpha /^{\circ}$ & 90 \\
\hline$\beta /^{\circ}$ & $101.765(2)$ \\
\hline$\gamma /{ }^{\circ}$ & 90 \\
\hline Volume $/ \AA^{3}$ & $4685.5(2)$ \\
\hline $\mathrm{Z}$ & 4 \\
\hline$\rho$ calcg $/ \mathrm{cm}^{3}$ & 1.5324 \\
\hline $\mathrm{F}(000)$ & 2231.8 \\
\hline Crystal size $/ \mathrm{mm}^{3}$ & $\mathrm{~N} / \mathrm{A} \times \mathrm{N} / \mathrm{A} \times \mathrm{N} / \mathrm{A}$ \\
\hline Radiation $/ \AA ̊$ & Mo Ka $(\lambda=0.71073)$ \\
\hline $2 \Theta$ range for data collection $/^{\circ}$ & 3.5 to 64.22 \\
\hline Reflections collected & 30,842 \\
\hline Independent reflections & $14,639\left[R_{\text {int }}=0.0337, R_{\text {sigma }}=0.0595\right]$ \\
\hline Reflections with $I>=2 u(I)$ & 10,704 \\
\hline Goodness-of-fit on $\mathrm{F}^{2}$ & 1.041 \\
\hline Final R indexes $[I>=2 u(I)]$ & $\mathrm{R}_{1}=0.0558, \mathrm{wR}_{2}=0.1313$ \\
\hline Final $\mathrm{R}$ indexes [all data] & $\mathrm{R}_{1}=0.0822, \mathrm{wR}_{2}=0.1500$ \\
\hline
\end{tabular}

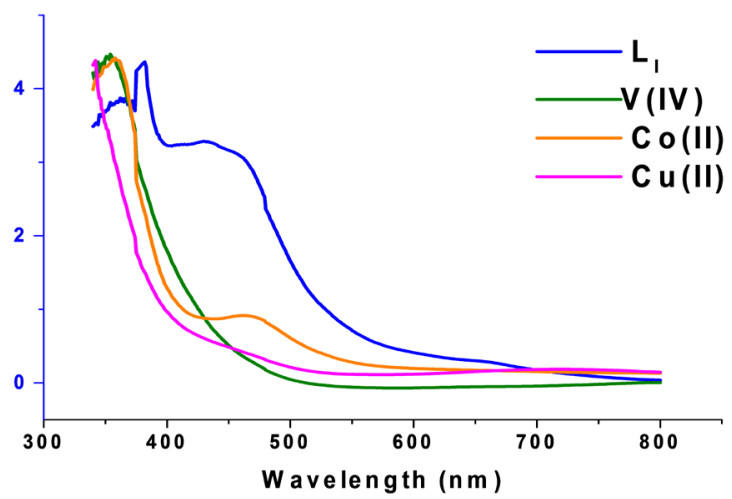

Figure 7. UV-visible spectra of Schiff base and VO(II), $\mathrm{Co}(\mathrm{II})$ and $\mathrm{Cu}(\mathrm{II})$ binuclear complexes. 


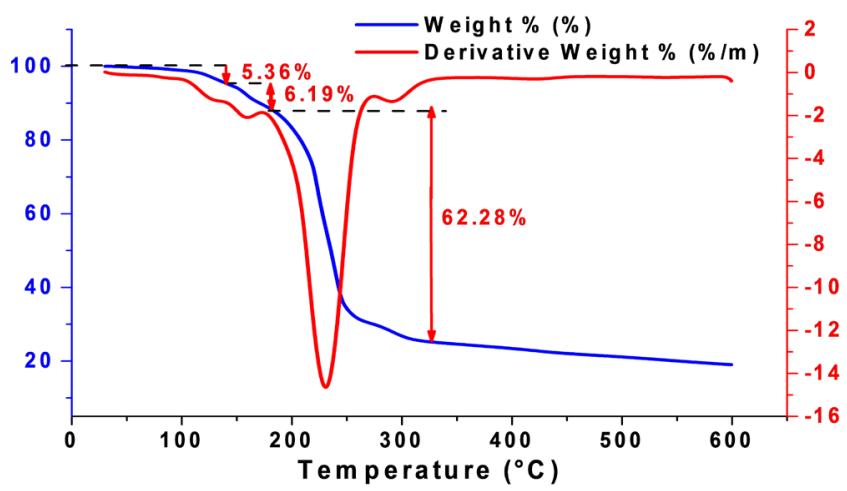

Figure 8. Thermogram of the $\left[\mathrm{Cu}_{2}\left(\mathrm{~L}_{2}\right)_{2}\left(\mathrm{~L}_{3}\right)_{2}\right]$ binuclear complex.

Table 6. Selected bond Lengths and bond Angles for $\mathrm{C}_{51} \mathrm{H}_{40} \mathrm{Cu}_{2} \mathrm{~N}_{7} \mathrm{O}_{12}$.

\begin{tabular}{|c|c|c|c|c|}
\hline Atom & & Atom & & Length/Å \\
\hline $\mathrm{Cul}$ & & $\mathrm{Cu} 2$ & & $3.0301(4)$ \\
\hline $\mathrm{Cu} 1$ & & $\mathrm{O} 11$ & & $1.9280(18)$ \\
\hline $\mathrm{Cu} 1$ & & O26 & & $1.9600(17)$ \\
\hline $\mathrm{Cu} 1$ & & O61 & & $2.475(2)$ \\
\hline $\mathrm{Cu} 1$ & & N12 & & $1.986(2)$ \\
\hline $\mathrm{Cu} 1$ & & N46 & & $2.007(2)$ \\
\hline $\mathrm{Cu} 2$ & & O11 & & $1.9321(17)$ \\
\hline $\mathrm{Cu} 2$ & & O26 & & $1.9097(18)$ \\
\hline $\mathrm{Cu} 2$ & & O54 & & $2.420(2)$ \\
\hline $\mathrm{Cu} 2$ & & N32 & & $1.983(2)$ \\
\hline $\mathrm{Cu} 2$ & & N47 & & $1.981(2)$ \\
\hline 011 & & $\mathrm{C} 9$ & & $1.399(3)$ \\
\hline $\mathrm{O} 40$ & & C39 & & $1.226(3)$ \\
\hline $\mathrm{O} 25$ & & $\mathrm{C} 24$ & & $1.403(3)$ \\
\hline N12 & & $\mathrm{C} 13$ & & $1.341(3)$ \\
\hline Atom & Atom & & Atom & Angle ${ }^{\circ}$ \\
\hline 011 & $\mathrm{Cu} 1$ & & $\mathrm{Cu} 2$ & $38.33(5)$ \\
\hline $\mathrm{O} 26$ & $\mathrm{Cu} 1$ & & $\mathrm{Cu} 2$ & $37.87(5)$ \\
\hline $\mathrm{O} 26$ & $\mathrm{Cu} 1$ & & O11 & $76.15(7)$ \\
\hline 061 & $\mathrm{Cu} 1$ & & $\mathrm{Cu} 2$ & $88.88(5)$ \\
\hline 061 & $\mathrm{Cu} 1$ & & O11 & $89.34(8)$ \\
\hline O61 & $\mathrm{Cul}$ & & O26 & $86.35(8)$ \\
\hline N12 & $\mathrm{Cu} 1$ & & $\mathrm{Cu} 2$ & $119.91(7)$ \\
\hline N12 & $\mathrm{Cu} 1$ & & O11 & $81.61(8)$ \\
\hline N12 & $\mathrm{Cu} 1$ & & O26 & $157.75(8)$ \\
\hline $\mathrm{N} 12$ & $\mathrm{Cu} 1$ & & O61 & $93.16(8)$ \\
\hline N46 & $\mathrm{Cu} 1$ & & $\mathrm{Cu} 2$ & $138.11(6)$ \\
\hline N46 & $\mathrm{Cu} 1$ & & $\mathrm{O} 11$ & $174.14(9)$ \\
\hline N46 & $\mathrm{Cu} 1$ & & $\mathrm{O} 26$ & $100.71(8)$ \\
\hline
\end{tabular}


The molecular structure of the binuclear $\mathrm{Cu}(\mathrm{II})$ complex is given in Figure 9 and the crystallographic data summarized in Table 5. The complex crystallizes in a monoclinic crystal system with two ligands in the unit cell just like the reported structure [27]. The selected bond lengths and angles are shown in Table 6. The molecular structure of the complex consists of a non-centro symmetric $\left[\mathrm{Cu}_{2}\left(\mathrm{~L}_{1}\right)_{2}\left(\mathrm{~L}_{3}\right)_{2}\right]^{2+}$ cation, a water molecule, an ethanolate ion and two nitrate ions. The two copper atoms are separated by a distance of $3.023 \AA$ comparable to that reported for bridged alkoxo complexes. On the other hand, the bridge angles $\mathrm{Cu}(1)-\mathrm{O}(11)-\mathrm{Cu}(2)$ and $\mathrm{Cu}(1)-\mathrm{O}(26)-\mathrm{Cu}(2)$ of $38.33^{\circ}(5)$ and $37.87^{\circ}(5)$ are different from those observed for other alkoxo complexes [27]. The bond lengths $(\mathrm{Cu}(1)-\mathrm{N}($ py) are respectively $[\mathrm{Cu}(1)-\mathrm{N}(12)=1.986(2) \AA$ and $\mathrm{Cu}(1)-\mathrm{N}(46)=$ 2.007(2) $\AA$ ] and compare well with those found in the reported binuclear copper(II) complexes[27] [28].

\section{Biological Activity of the Synthesized Compounds}

\subsection{Antimicrobial Activity of the Schiff Base and Binuclear Metal Complexes}

The Schiff base and complexes were tested against three bacterial strains Staphylococcus aureus, Klebsiella pneumoniae and Eschericia coli and three fungal strains Candida albicans, Candida glabrata and Candida parapsilosis. Rifampicin and Fluconazole were used as the standards for bacterial and fungal studies respectively. The diameters of the zone of inhibition of the ligand and binuclear complexes were determined using disc diffusion method [23]. The diameters of zone of inhibition of the bacteria are summarized in Table 7. The results reveal that the Schiff base and the binuclear complexes do not exhibit antifungal activities but for the Cobalt complex which exhibited moderate activity against the $C$. albicans species. The antifungal activity of $\mathrm{Co}$ (II) complex on $C$. albicans is comparable to the activity of Rifampicin used as standard. [(VO) $\left.{ }_{2}\left(\mathrm{~L}_{2}\right)_{2}\right]$ complex exhibited high antibacterial activity on all the tested species, when compared to Rifampicin used as standard.

Table 7. Diameters of inhibition zones at the end of the screening.

\begin{tabular}{ccccccc}
\hline & \multicolumn{3}{c}{ Bacteria } & & Fungi \\
\cline { 2 - 6 } Compounds & Eschericia coli & $\begin{array}{c}\text { Klebsiella } \\
\text { pneumoniae }\end{array}$ & $\begin{array}{c}\text { Staphylococcus } \\
\text { aureus }\end{array}$ & $\begin{array}{c}\text { Candida } \\
\text { albicans }\end{array}$ & $\begin{array}{c}\text { Candida } \\
\text { glabrata }\end{array}$ & $\begin{array}{c}\text { Candida } \\
\text { parapsilosis }\end{array}$ \\
\hline $\mathrm{L}_{\mathrm{I}}$ & - & - & - & - & - & - \\
{$\left[(\mathrm{VO})_{2}\left(\mathrm{~L}_{2}\right)_{2}\right]$} & $15 \pm 0.8$ & $13 \pm 1.01$ & $15 \pm 0.23$ & - & - & - \\
{$\left[\mathrm{Co}_{2}\left(\mathrm{~L}_{2}\right)\left(\mathrm{L}_{3}\right)_{2}\right]$} & - & - & - & - & - & - \\
{$\left[\mathrm{Cu}_{2}\left(\mathrm{~L}_{2}\right)_{2}\left(\mathrm{~L}_{3}\right)_{2}\right]$} & - & - & - & - & - & - \\
$\mathrm{Control} \quad$ Fluconazole & $/$ & $18 \pm 1.6$ & $22 \pm 1.05$ & $/$ & $/$ & $2.3 \pm 1.08$ \\
\hline
\end{tabular}

Compounds are considered active when their diameters of the zone of inhibition are greater than $6 \mathrm{~mm}(\mathrm{DZI}>6 \mathrm{~mm})$ and $(-)$ means no activities observed. 


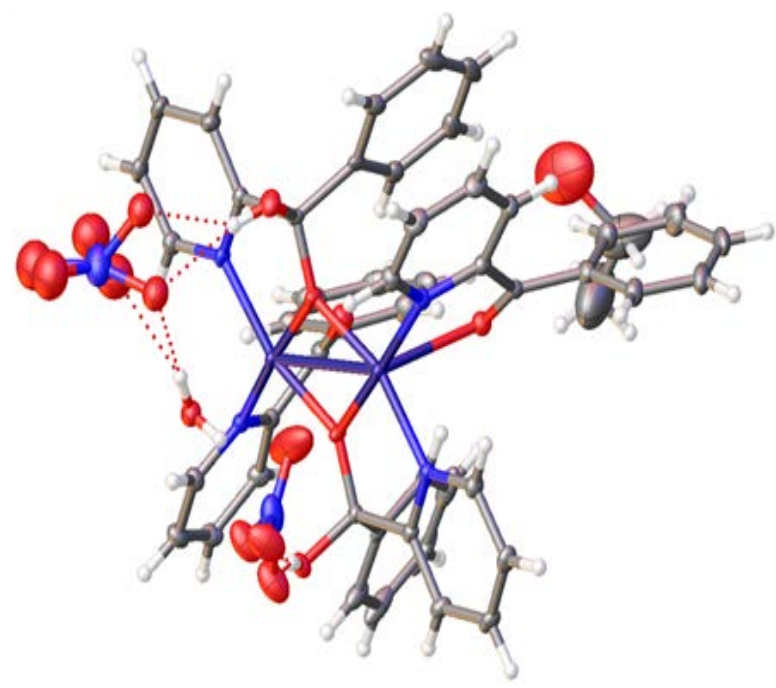

(a)

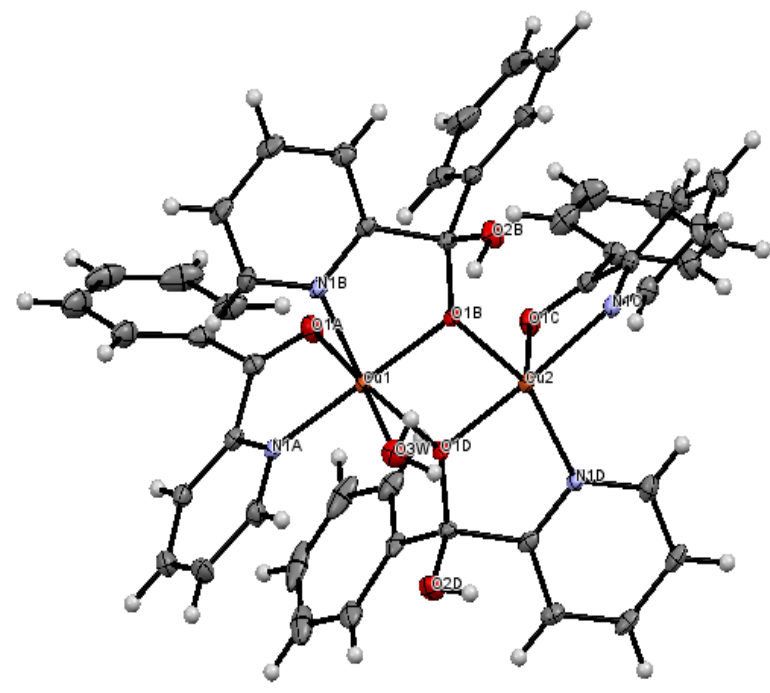

(b)

Figure 9. Molecular structure of complex (a) $\left[\mathrm{Cu}_{2}\left(\mathrm{~L}_{1}\right)_{2}\left(\mathrm{~L}_{3}\right)_{2}\right]\left(\mathrm{NO}_{3}\right)_{2} \cdot \mathrm{H}_{2} \mathrm{O} \cdot \mathrm{CH}_{3} \mathrm{CH}_{2} \mathrm{O}$ (this work); (b) $\left[\mathrm{Cu}_{2}\left(\mathrm{~L}_{1}\right)_{2}\left(\mathrm{~L}_{3}\right)_{2}\right]\left(\mathrm{NO}_{3}\right)_{2} \cdot \mathrm{H}_{2} \mathrm{O}[27]$.

\subsection{Anti-Radical Activities of Synthetic Products}

\subsubsection{DPPH Free Radical Scavenging Test}

The synthesized compounds were screened for their free radical scavenging activities by DPPH method using Vitamin $\mathrm{C}$ as a standard. Antioxidant activities of these compounds were investigated by determining the concentration of substance necessary to reduce $50 \%$ of the $\mathrm{DPPH}^{\cdot}$ radical ( $\mathrm{EC}_{50}$ values) of each compound. The results of the determination of $\mathrm{EC}_{50}$ values of the compounds are shown in Table 8. It is evident from these results that, all the compounds do not exhibited antiradical activity even at different concentrations. This observation could be due to the absence of proton in the Schiff base structure and the deprotonation of gem-diol proton in the complexes during chelation.

\subsubsection{Ferric Ion Reducing Antioxidant Power Assay (FRAP) Test}

The reducing powers of the compounds are associated with their antiradical power. The reducing powers of the synthesized compounds were determined using the FRAP method. This technique determines the ability of the tested compounds to reduce ferric iron $\left(\mathrm{Fe}^{3+}\right)$ present in $\mathrm{K}_{3} \mathrm{Fe}(\mathrm{CN})_{6}$ complex to ferrous iron $\left(\mathrm{Fe}^{2+}\right)[38]$. Only $\left[(\mathrm{VO})_{2}\left(\mathrm{~L}_{2}\right)_{2}\right]$ and $\left[\mathrm{Co}_{2}\left(\mathrm{~L}_{2}\right)\left(\mathrm{L}_{3}\right)_{2}\right]$ showed reduction capacity which are presented in Figure 10 and Figure 11. It is evident from these results that, the reducing ability of the compounds are concentration dependent [39].

From the result, we find that the reduction of iron by the FRAP method is more pronounced by $\left[\left(\mathrm{VO}_{2}\right)\left(\mathrm{L}_{2}\right)_{2}\right]$ and $\left[\mathrm{Co}_{2}\left(\mathrm{~L}_{2}\right)\left(\mathrm{L}_{3}\right)_{2}\right]$ complexes with maxima at Optical Density, $\mathrm{OD}=2.87$ and 2.94. We can deduce that $\left[\left(\mathrm{VO}_{2}\right)\left(\mathrm{L}_{2}\right)_{2}\right]$ and $\left[\mathrm{Co}_{2}\left(\mathrm{~L}_{2}\right)\left(\mathrm{L}_{3}\right)_{2}\right]$ complexes have the capacity to reduce iron. This ability to reduce iron is greater than that of ascorbic acid $(\mathrm{OD}=2.12)$, employed as standard. Thus, the antioxidant activity of these complexes can be attributed to the oxidation of $\mathrm{Co}(\mathrm{II})$ to $\mathrm{Co}(\mathrm{III})$ and $\mathrm{V}(\mathrm{IV})$ to $\mathrm{V}(\mathrm{V})$ during the reduction of Iron(III) to Iron(II). 
Table 8. $\mathrm{EC}_{50}$ data of Schiff base and binuclear complexes.

\begin{tabular}{ccc}
\hline Samples & $\mathrm{EC}_{50}(\mu \mathrm{g} / \mathrm{mL})$ & $\mathrm{EC}_{50} \times 10^{3}(\mu \mathrm{g} / \mathrm{mL})$ \\
\hline $\mathrm{L}_{1}$ & $/$ & - \\
{$\left[(\mathrm{VO})_{2}\left(\mathrm{~L}_{2}\right)_{2}\right]$} & $/$ & - \\
{$\left[\mathrm{Co}_{2}\left(\mathrm{~L}_{2}\right)\left(\mathrm{L}_{3}\right)_{2}\right]$} & $/$ & - \\
{$\left[\mathrm{Cu}_{2}\left(\mathrm{~L}_{2}\right)_{2}\left(\mathrm{~L}_{3}\right)_{2}\right]$} & $/$ & $0.652 \pm 0.029^{\mathrm{a}}$ \\
$\mathrm{VitC}$ & $9.777 \pm 0.520^{\mathrm{a}}$ & \\
\hline
\end{tabular}

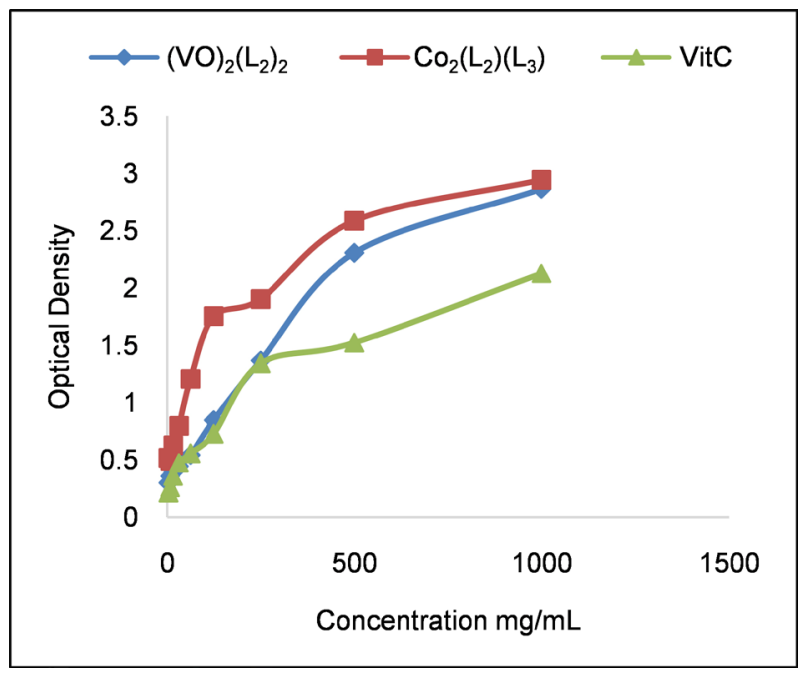

Figure 10. Ferric ion reducing power of the complexes $\left[\left(\mathrm{VO}_{2}\right)\left(\mathrm{L}_{1}\right)_{2}\right],\left[\mathrm{Co}_{2}\left(\mathrm{~L}_{1}\right)\left(\mathrm{L}_{2}\right)_{2}\right]$ and Vitamin $\mathrm{C}$ at different concentrations.

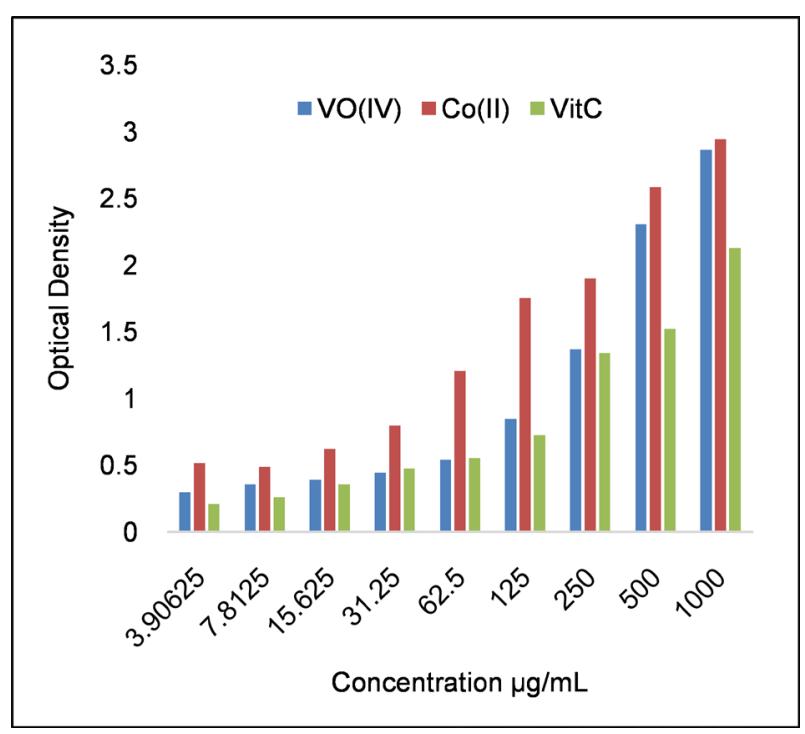

Figure 11. Histogram of the OD of VO(IV) and Co(II) complexes and Vitamin $\mathrm{C}$ studied by FRAP at different concentrations. 


\section{Conclusion}

We have synthesized a new Schiff base $\left(\mathrm{L}_{1}\right)$ derived from 2-aminopyrimidine and 2-benzoylpyridine. The reaction of 1-phenyl-1-(pyridin-2-yl)-N-(pyrimidin2-yl)methanimine dihydrate $\left(\mathrm{L}_{1}\right)$ with salts of $\mathrm{V}(\mathrm{IV}), \mathrm{Co}(\mathrm{II})$ and $\mathrm{Cu}(\mathrm{II})$ in a molar ratio of 2:1, resulted in the hydrolysis of $\mathrm{L}_{1}$ to give binuclear metal complexes of 2-benzoylpyridine $\left(\mathrm{L}_{2}\right)$ and phenyl(pyridin-2-yl)methanediol $\left(\mathrm{L}_{3}\right)$ and to give alkoxo bridged binuclear complexes. The results of elemental analysis, molar conductivity measurement and spectral analyzes (FT-IR, Uv-Vis) support the suggested structures of metal complexes. The Schiff base and some of the complexes showed no antimicrobial activity but for the $\left[(\mathrm{VO})_{2}\left(\mathrm{~L}_{2}\right)_{2}\right]$ complex which was found to be active against Eschericia coli, Klebsiella pneumoniae, Staphylococcus aureus strains. Antioxidant test results revealed that $\left[(\mathrm{VO})_{2}\left(\mathrm{~L}_{2}\right)_{2}\right]$ and $\left[\mathrm{Co}_{2}\left(\mathrm{~L}_{2}\right)\left(\mathrm{L}_{3}\right)_{2}\right]$ complexes had higher activity than the reference antioxidant (vi$\operatorname{tamin} \mathrm{C})$.

\section{Acknowledgements}

The authors acknowledge the Faculty of Chemistry, Bielefeld University (Germany) and the Department of Chemistry of the University of Zululand (South Africa) for helping with some of the analysis. The authors thank Dr. Hans-Georg Stammler of the Faculty of Chemistry, Bielefeld University for X-ray crystal structure data.

\section{Funding}

This work was partly funded under the "Fond de modernisation et d appui a la recherche" state subsidy to Higher Education University Teachers of Cameroon.

\section{Conflicts of Interest}

The authors declare no conflicts of interest regarding the publication of this paper.

\section{References}

[1] Pandey, S. and Srivastava, R.S. (2011) Synthesis and Characterization of Some Heterocyclic Schiff Bases: Potential Anticonvulsant Agents. Medicinal Chemistry Research, 20, 1091-1101. https://doi.org/10.1007/s00044-010-9441-Z

[2] Fromm, K.M. (2013) Silver Coordination Compounds with Antimicrobial Properties. Applied Organometallic Chemistry, 27, 683-687. https://doi.org/10.1002/aoc.3047

[3] Glišić, B.D. and Djuran, M.I. (2014) Gold Complexes as Antimicrobial Agents: An Overview of Different Biological Activities in Relation to the Oxidation State of the Gold Ion and the Ligand Structure. Dalton Transactions, 43, 5950-5969. https://doi.org/10.1039/C4DT00022F

[4] Polo-Cerón, D. (2019) $\mathrm{Cu}(\mathrm{II})$ and Ni(II) Complexes with New Tridentate NNS Thiosemicarbazones: Synthesis, Characterisation, DNA Interaction, and Antibacterial Activity. Bioinorganic Chemistry and Applications, 2019, Article ID: 3520837. 
https://doi.org/10.1155/2019/3520837

[5] Alwan, S.M. and Al-Kaabi, J.A-S. (2014) Synthesis and Preliminary Antimicrabial Activity of New Schiff Bases of Pyrido[1,2-a] Pyrimidine Derivatives with Certain Amino Acid. Medicinal Chemistry, 4, 635-639. https://doi.org/10.4172/2161-0444.1000206

[6] Chioma, F., Ekennia, A.C., Osowole, A.A., Okafor, S.N., Ibeji, C.U., Onwudiwe, D.C. and Ujam, O.T. (2018) Synthesis, Characterization, In-Vitro Antimicrobial Properties, Molecular Docking and DFT Studies of 3-\{(E)-[(4,6-dimethylpyrimidin2-yl)imino]methyl\}naphthalen-2-ol and Heteroleptic $\mathrm{Mn}(\mathrm{II}), \mathrm{Co}(\mathrm{II}), \mathrm{Ni}(\mathrm{II})$ and $\mathrm{Zn}(\mathrm{II})$ Complexes. Open Chemistry, 16, 184-200. https://doi.org/10.1515/chem-2018-0020

[7] Amr, E.A., Ashraf, M.M., Salwa, F.M., Nagla, A.A. and Hammam, A.G. (2006) Anticancer Activities of Some Newly Synthesized Pyridine, Pyrane, and Pyrimidine Derivatives. Bioorganic and Medicinal Chemistry, 14, 5481-5488.

https://doi.org/10.1016/j.bmc.2006.04.045

[8] Srivastva, A.N., Singh, N.P. and Shriwastaw, C.K. (2016) In Vitro Antibacterial and Antifungal Activities of Binuclear Transition Metal Complexes of ONNO Schiff Base and 5-Methyl-2,6-pyrimidine-dione and Their Spectroscopic Validation. Arabian Journal of Chemistry, 9, 48-61. https://doi.org/10.1016/j.arabjc.2014.10.004

[9] Bencini, A., Ciofini, I., Daul, C.A. and Ferretti, A. (1999) Ground and Excited State Properties and Vibronic Coupling Analysis of the Creutz-Taube Ion, $\left[\left(\mathrm{NH}_{3}\right)_{5} \mathrm{Ru}-\right.$ pyrazine- $\left.\mathrm{Ru}\left(\mathrm{NH}_{3}\right)_{5}\right)^{5+}$, Using DFT. Journal of the American Chemical Society, 121, 11418-11424. https://doi.org/10.1021/ja9920258

[10] Arun, T., Subramanian, R. and Raman, N. (2016) Novel Bio-Essential Metal Based Complexes Linked by Heterocyclic Ligand: Synthesis, Structural Elucidation, Biological Investigation and Docking Analysis. Journal of Photochemistry and Photobiology B, 154, 67-76. https://doi.org/10.1016/j.jphotobiol.2015.11.011

[11] Garagorri, D.B. and Kirchner, K. (2008) Modularly Designed Transition Metal PNP and PCP Pincer Complexes Based on Aminophosphines: Synthesis and Catalytic. Accounts of Chemical Research, 41, 201. https://doi.org/10.1021/ar700129q

[12] Gruenwald, K.R., Kirillov, A.M., Haukka, M., Sanchiz, J. and Pombeiro, A.J.L. (2009) Mono-, Di- and Polynuclear Copper(II) Compounds Derived from N-butyldiethanolamine: Structural Features, Magnetism and Catalytic Activity for the Mild Peroxidative Oxidation of Cyclohexane. Dalton Transactions, 12, 2109-2120. https://doi.org/10.1039/b813160k

[13] Venegas-Yazigi, D., Aravena, D., Spodine, E., Ruiz, E. and Alvarez, S. (2010) Structural and Electronic Effects on the Exchange Interactions in Dinuclear Bis (phenoxo)-Bridged Copper(II) Complexes. Coordination Chemistry Reviews, 254, 2086-2095. https://doi.org/10.1016/j.ccr.2010.04.003

[14] Wannarit, N., Siriwong, K., Chaichit, N., Youngme, S., Costa, R., Moreira, I.P.R. and Illas, F. (2011) New Series of Triply Bridged Dinuclear Cu(II) Compounds: Synthesis, Crystal Structure, Magnetic Properties, and Theoretical Study. Inorganic Chemistry, 50, 10648-10659. https://doi.org/10.1021/ic200992z

[15] Cordes, E.H. and Jencks, W.P. (1962) On the Mechanism of Schiff Base Formation and Hydrolysis. Journal of the American Chemical Society, 84, 832-837. https://doi.org/10.1021/ja00864a031

[16] El-Taher, M.A. (1998) Acceleration Effect of $\mathrm{Fe}(\mathrm{II}), \mathrm{Ni}(\mathrm{II})$ and $\mathrm{Cu}(\mathrm{II})$ on the Hydrolysis Rate of Ortho- or Para-Hydroxy Schiff Bases. Journal of the Chinese Chemical Society, 45, 815-820. https://doi.org/10.1002/jccs.199800123 
[17] Kumar Naik, K.H., Selvaraj, S. and Naik, N. (2014) Metal Complexes of ONO Donor Schiff Base Ligand as a New Class of Bioactive Compounds; Synthesis, Charactization and Biological Evolution. Spectrochimica Acta, Part A, Molecular and Biomolecular Spectroscopy, 131, 599-605. https://doi.org/10.1016/j.saa.2014.03.038

[18] Hossain, M.E., Atam, M.N., Begum, J., Akbar Ali, M. and Nazimuddin, M. (1993) The Preparation, Characterization, Crystal Structure and Biological Activities of Some Copper(II) Complexes of the 2-Benzoylpyridine Schiff Bases of $S$-Methyl- and S-Benzyldithiocarbazate. Transition Metal Chemistry, 18, 497. https://doi.org/10.1007/BF00136613

[19] Das, K., Jana, A., konar, S., Chatterjee, S., Mondal, T.K., Barik, A.K. and Kar, A.K. (2013) A New Trinuclear Zinc(II) Complex and a Heptacoordinated Mononuclear Cadmium(II) Complex with an Pyrimidine Derived Schiff Base Ligand: Syntheses, Cristal Structures, Photoluminescence and DFT Calculations. Journal of Molecular Structure, 1048, 98-107. https://doi.org/10.1016/j.molstruc.2013.05.020

[20] Dolomanov, O.V., Bourhis, L.J., Gildea, R.J., Howard, J.A.K. and Puschmann, H. (2009) OLEX2: A Complete Structure Solution, Refinement and Analysis Program. Journal of Applied Crystallography, 42, 339-341. https://doi.org/10.1107/S0021889808042726

[21] Sheldrick, G.M. (2015) SHELXT-Integrated Space-Group and Crystal-Structure Determination. Acta Crystallographica Section A: Foundations, 71, 3-8. https://doi.org/10.1107/S2053273314026370

[22] Bauer, A.W., Kirby, W.M., Sherris, J.C. and Turck, M. (1966) Antibiotic Susceptibility Testing by a Standardized Single Disk Method. American Journal of Clinical Pathology, 45, 493-496. https://doi.org/10.1093/ajcp/45.4_ts.493

[23] Blois, M.S. (1958) Antioxidant Determinations by the Use of a Stable Free Radical. Nature, 181, 1199-1200. https://doi.org/10.1038/1811199a0

[24] Benzie, I.F. and Strain, J.J. (1996) The Ferric Reducing Ability of Plasma (FRAP) as a Measure of "Antioxidant Power": The FRAP Assay. Analytical Biochemistry, 239, 70-76. https://doi.org/10.1006/abio.1996.0292

[25] Topacli, C. and Topacli, A. (2002) Infrared Spectra Simulation for Some Sulfonamides by Using Semi-Empirical Methods. Spectroscopy Letters, 35, 207-217. https://doi.org/10.1081/SL-120003806

[26] Aue, W.P., Bartholdi, E. and Ernst, R.R. (1976) Two-Dimensional Spectroscopy Application to Nuclear Magnetic Resonance. Journal of Chemical Physics, 64, 2229-2246. https://doi.org/10.1063/1.432450

[27] Dey, S., Sarkar, S., Zangrando, E., Evans, H.S., Sutter, J.-P. and Chattopadhyay, P. (2011) 2-Benzoylpyridine and Copper(II) Ion in Basic Medium: Hydroxide Nucleophilic Addition Stabilized by Metal Complexation, Reactivity, Crystal Structure, DNA, Binding Study and Magnetic Behavior. Inorganica Chimica Acta, 367, 1-8. https://doi.org/10.1016/j.ica.2010.11.012

[28] Ram, N.P., Yogendra, P.S., Yogendra, S., Butcherband, R.J. and Zeller, M. (2016) Unprecedented Copper(II) Mediated in Situ Formation of Gem-Diol Binuclear Complexes: A Combined Experimental and Computational Study. RSC Advances, 6, 107379-107398. https://doi.org/10.1039/C6RA20367A

[29] Knight, J.C., Amoroso, A.J., Edwards, P.G. Prabaharan, R. and Singh, N. (2010) The Co-Ordination Chemistry of Bis(2,2'-bipyrid-6'-yl)ketone with First Row Transition Metals: The Reversible Interconversion of a Mononuclear Complex and a Dinuclear Hemiketal Containing Species. Dalton Transactions, 39, 8925-8936. https://doi.org/10.1039/c0dt00344a 
[30] Rebolledo, A.P., de Lima, G.M., Gambi, L.N., Speziali, N.L., Maia, D.F., Pinheiro, C.B., Ardisson, J.D., Cortes, M.E. and Beraldo, H. (2003) Tin(IV) Complexes of 2-Benzoylpyridine N(4)-phenyl-thiosemicarbazone: Spectral Characterization, Structural Studies and Antifungal Activity. Applied Organometallic Chemistry, 17, 945-951. https://doi.org/10.1002/aoc.547

[31] Mohamed, G.G., Omar, M.M., and Brahim, A.A. (2009) Biological Activity Studies on Metal Complexes of Novel Tridentate Schiff Base Ligand. Spectroscopic and Thermal Characterization. European Journal of Medicinal Chemistry, 44, 4801-4812. https://doi.org/10.1016/j.ejmech.2009.07.028

[32] Nofal, Z.M., El-Zahar, M.I. and Abd El-Karim, S.S. (2000) Novel Coumarin Derivatives with Expected Biological Activity. Molecules, 5, 99-113. https://doi.org/10.3390/50200099

[33] Imran, A., Waseem, A.W. and Kishwar, S. (2013) Empirical Formulae to Molecular Structures of Metal Complexes by Molar Conductance. Synthesis and Reactivity in Inorganic, Metal-Organic, and Nano-Metal Chemistry, 43, 1162-1170. https://doi.org/10.1080/15533174.2012.756898

[34] Geary, W.J. (1971) The Use of Conductivity Measurements in Organic Solvents for the Characterisation of Coordination Compounds. Coordination Chemistry Reviews, 7, 81. https://doi.org/10.1016/S0010-8545(00)80009-0

[35] Mendes, I.C., Botion, L.M., Ferreira, A.V., Castellano, E.E. and Beraldo, H. (2009) Vanadium Complexes with 2-Pyridineformamide Thiosemicarbazones: In Vitro Studies of Insulinlike Activity. Inorganica Chimica Acta, 362, 414-420. https://doi.org/10.1016/j.ica.2008.04.029

[36] Kasumov, T.V., Koksal, F., Aslanoglu, M. and Yerli, Y. (2010) Synthesis, Spectroscopic Characterization and Reactivity Studies of Oxovanadium(IV) Complexes with Bulky N,N'-polymethylenebis $\left(3,5-{ }^{\mathrm{t}} \mathrm{Bu}_{2}\right.$ salicylaldimine) Ligands. Spectrochimica Acta, Part A, 77, 630-637. https://doi.org/10.1016/j.saa.2010.06.040

[37] Ahmadi, R.A., Hasanvand, F., Bruno, G., Rudbari, H.A. and Amani, S. (2013) Synthesis, Spectroscopy, and Magnetic Characterization of Copper(II) and Cobalt(II) Complexes with 2-Amino-5-bromopyridine as Ligand. Russian Journal of Coordination Chemistry, 39, 867-871. https://doi.org/10.1134/S1070328413110018

[38] Karagôzler, A., Erdag, C.S. and Çalmaz, E.Y. (2008) Antioxydant Activity and Proline Content of Leaf Extracts from Dorystoechas Hastate. Food Chemistry, 111, 400-407. https://doi.org/10.1016/j.foodchem.2008.03.089

[39] Liu, L.X., Sun, Y., Laura, T.L., Liang, X.F., Ye, H. and Zeng, X.X. (2009) Determination of Polyphenolic Content and Antioxidant Activity of Kudingcha Made from Ilex Kudingcha. Food Chemistry, 112, 35-41.

https://doi.org/10.1016/j.foodchem.2008.05.038 